Al-QANTTARA (AQ)

XXVII 2, julio-diciembre de 2006

pp. $477-527$

ISSN 0211-3589

\title{
CON LA GUÍA DEL CORÁN: CRISIS Y EVOLUCIÓN DEL DISCURSO NUMISMÁTICO ALMOHADE
}

\author{
SALVADOR PEÑA MARTíN \\ Universidad de Málaga \\ Miguel Vega Martín \\ Archivo Diocesano de Málaga
}

\begin{abstract}
Partimos de un recorrido histórico por acuñaciones almohades o postalmohades que, o bien no han sido registradas, o bien necesitan nuevas lecturas o atribuciones. Ello nos permite ofrecer una hipótesis sobre las monedas de plata acuñadas por Idrīs al-Ma'mūn y añadir algunos registros al corpus numismático del Occidente islámico en la Baja Edad Media. Ese trabajo nos permite, por otro lado, afrontar el discurso islámico dominante que surgió a raíz de la llamada revolución almohade, lo que hacemos centrándonos en varias cuestiones, entre ellas: 1) la densidad del mensaje sobre la vida eterna en las inscripciones almohades, que derivan de la fuente absoluta del Corán; 2) el problema de si es necesaria, de cara a la salvación, la presencia de guías históricos; 3 ) la evolución de la teología negativa a la afirmativa, y 4) la estrecha relación entre el discurso numismático y las elites almohades y postalmohades.
\end{abstract}

Palabras clave: Monedas; teología; almohades; Corán; Occidente islámico.
First, we examine some unregistered Almohad and Post-Almohad coins, and discuss the attribution or reading of some others. As a result a discussion of a hypothesis on Idrīs al-Ma'mūn's silver coins is offered and some new items are added to the numismatic corpus of Western Islam. This work leads us to a general overview of the Islamic discourse prevailing in Islamic Spain and North Africa after the so-called Almohad revolution. Considering this discourse as a dynamic work in progress, we focus on a number of issues: (1) the Qur'ānic aim of eternal life as a touchstone in the Almohad system of ideas, (2) the issue whether salvation is possible without actual human guides, (3) the evolution from negative to affirmative theology, (4) the ties binding the numismatic discourse and the Almohad and Post-Almohad ruling classes.

Keywords: Coins; Theology; Almohads; Qur'ān; Western Islam. 


\section{Principio ${ }^{1}$ de legitimidad}

En el Corán (4 al-Nisa $\bar{a}, 59)$ se sienta el principio islámico del poder legítimo ${ }^{2}$ :

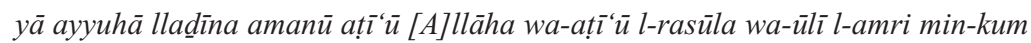
(creyentes: obedeced a Dios, y obedeced al Enviado y a los capaces de disposición de entre vosotros) ${ }^{3}$.

Los traductores contemporáneos suelen coincidir en la noción de obediencia y, algo menos, en la referencia exacta del término (amr) que acabamos de traducir por «disposición», y que se suele entender como «autoridad» ${ }^{4}$. Así, J. Cortés traduce ${ }^{5}$ :

¡Creyentes! Obedeced a Dios, obedeced al Enviado y a aquéllos de vosotros que tengan autoridad.

El Discurso divino establece, pues, que la comunidad debe someterse a tres instancias de poder, Dios, Muhammad y una tercera, que es designada por la expresión ūlū l-amr (capaces de disposición, dotados de autoridad); y, si bien no queda duda de que los así llamados deben proceder de la propia comunidad, históricamente no siempre se ha interpretado del mismo modo a qué sujetos concretos designa ${ }^{6}$. Es

1 Agradecemos a Ali Faiz, Rafael Frochoso, Edmund Hohertz, Muhammad S. Jazzar, Majed Mehdi, Miguel Ángel Manzano Rodríguez, Marc Pelletier, José Miguel Puerta Vílchez y Jaime Pérez su ayuda en materia de documentación; al Museo Arqueológico y Etnológico de Córdoba y al Museo Arqueológico y Etnológico de Granada, las facilidades para el estudio de sus fondos numismáticos; a Maribel Fierro, sus valiosos comentarios al penúltimo borrador de este escrito, y a David Wasserstein, sus concienzudos comentarios al último.

2 Cf. Fierro, M., "La legitimidad del poder en el islam", Awrāq, 15 (1994), 147-184, y "On political legitimacy in al-Andalus", Der Islam, 73 (1986), 138-150; y Lewis, B., El lenguaje político del islam, Lucini, M. (trad.), Madrid, 2004, 152 y ss.

3 Las traducciones que se incluyen a continuación de las citas en árabe, que son nuestras salvo que se indique lo contrario, tienen como única función el hacer accesible el razonamiento.

${ }^{4}$ Cf. Arberry, A. J., The Koran Interpreted, Oxford U. P., 1964 [1955]: "those in authority among you"; Il Corano, trad. Bausani, A., Milán, 1999 [1955]: "quelli di voi che detengono l'autorità"; L'Alcorà, trad. Epalza, M. de, Barcelona, 2001: "els qui tenen, d'entre vosaltres, l'autoritat"; Le Coran, trad. Kazimirski, A. de B., París, 1981 [1840]: "à ceux d'entre vous qui exercent l'autorité"; Le Coran, trad. Masson, D., París, 1967: "ceux d'entre vous qui détiennent l'autorité". Y, en contraposición, Le saint Coran et la traduction en langue française du sens de ses versets, trad. Complexe du Roi Fahd [a partir de Hamidullah, M.], Medina, 1410 h.: "ceux d'entre vous qui détiennent le commandement".

${ }^{5}$ El Corán, trad. Cortés, J., Barcelona, 1999.

${ }^{6}$ Cf., por ejemplo, Waines, D., El islam, Pérez-Benítez, C. (trad.), Madrid, 2002², $61 \mathrm{y}$ ss.

Al-Qanțara (AQ) XXVII 2, julio-diciembre 2006, pp. 477-527 ISSN 0211-3589 
un hecho constatable que los Mu'miníes entendían que el término en cuestión, al-amr (la disposición) ${ }^{7}$, designaba a la empresa por ellos encabezada, lo que equivalía a identificar al movimiento almohade con la voluntad de Dios. De ahí que en los escritos oficiales mu'miníes se designe con dicho término coránico al propio «almohadismo» ${ }^{8}$. Ahora bien, es ampliamente aceptado por los historiadores del movimiento encabezado por Ibn Tümart que, entre los factores de la decadencia almohade ${ }^{9}$, se contó la debilidad del mecanismo de legitimación ${ }^{10}$, que consistía en hacer de los almohades los verdaderos $\bar{u} l \bar{u}$ l-amr (capaces de disposición, dotados de autoridad) en su momento y lugar, y ello, porque dicho mecanismo se basaba en dos elementos acaso divergentes: a) el mesianismo que se asocia al líder carismático, el imam o maestro, en este caso, Ibn Tūmart, y b) la legitimidad heredada dentro de una familia, la dinastía de los Mu'miníes, que, paradójicamente - y he ahí el problema - no eran descendientes de sangre de Ibn Tūmart, sino de su discípulo y lugarteniente, el califa o vicario 'Abd al-Mu'min ibn 'Alī. Y, en efecto, mientras que en la mayoría de las monedas almohades de oro se atribuye a Ibn Tūmart el título y función de al-qā’im bi-amr Allāh (el ejecutor de la disposición de Dios) ${ }^{11}$, el hecho es que los Mu'miníes adoptaron algunos signos de poder teocrático, correspondientes a

\footnotetext{
7 Sobre amr para los almohades, Fricaud, É., “Origine de l'utilisation privilégiée du term de amr chez les Mu'minides almohades", Al-Qanțara, XXIII, 1 (2002), 93-121, y Vega Martín, M., Peña Martín, S. y Feria García, M. C., El mensaje de las monedas almohades: numismática, traducción y pensamiento islámico, Cuenca, 2002. Por su parte, García-Arenal, M., "Messianisme juif aux temps des mahdi-s", Judios y musulmanes en al-Andalus y el Magreb: contactos intelectuales, ed. M. Fierro, Madrid, 2002, 211-229, ha estudiado el concepto en relación con el mesianismo en un ámbito mayor que el islámico. E igualmente la relación de $a m r$ con nociones paralelas en el ámbito del monoteísmo, la ha tratado Gaudefroy-Demombynes, M., Mahomet, París, $1969^{2}, 272$ y ss., y Gnilka, J., Biblia y Corán, Villanueva, M. (trad.), Barcelona, 2005, 131 y ss.

8 Documents inédits d'histoire almohade: fragments manuscrits du "Legajo" 1919 du fond arabe de l'Escurial, Lévi-Provençal, É. (ed. y trad.), París, 1928, 8 y pas.; Rasā'il muwahhhidiyya: Maŷmū'a ŷadìda (al-qism al-awwal), 'Azzawī, A. (ed.), Kenitra, 1995, 55 y pas.

9 Cf. Viguera Molíns, M. J., "Al-Andalus en época almohade", Andalucía entre Oriente y Occidente (1236-1492), ed. E. Cabrera, Córdoba, 1988, 9-29, 26-27.

${ }^{10}$ Cf. Fierro, M., "The legal policies of the Almohad caliphs and Ibn Rushd's Bidāyat al-mujtahid", Journal of Islamic Studies, 10, 3 (1999), 226-248, 243; Urvoy, D., Averroes: las ambiciones de un intelectual musulmán, trad. Serrano, D., Madrid, 1998, 60 y ss.

${ }^{11}$ García-Arenal, M., "Messianisme juif"; Vega Martín, M., Peña Martín, S. y Feria García, M. C., El mensaje de las monedas, 176 y ss.
}

Al-Qanțara (AQ) XXVII 2, julio-diciembre 2006, pp. 477-527 ISSN 0211-3589 
quienes ejercían esa disposición, la autoridad de la que habla el Corán, como el título amìr al-mu'minīn (emir de los creyentes) o de emblemas oficiales teóforos; así, por ejemplo, Abū Yūsuf Ya'qūb I adoptó el sobrenombre al-Manșür bi-Faḍl Allāh (socorrido por el Favor de Dios) y en su anillo-sello se hizo grabar la confesión coráni ca ${ }^{12}$ 'Alā [A]lläh tawakkalt (a Dios me he encomendado) ${ }^{13}$. Por otro lado, el Libro sagrado arroja algo más de luz sobre la autoridad teocrática, en dos pasajes, muy similares, situados ambos en el contexto de la historia sagrada de los profetas. El primero lo constituyen unas palabras dirigidas por Dios a Muhammad, cuando éste va a encontrarse con Moisés (32 al-Saŷda, 23-24) — personaje modélico, Moisés, para la figura del dirigente almohade ${ }^{14}$ - y el segundo, de alcance más amplio, se refiere en general a los sucesores de Abraham (21 Al-Anbiyā', 73):

wa-la-qad ataynā Mūsà l-Kitāba fa-lā takun fì miryatin min liqā̇i-hi wa-ŷa 'alnā-hu hudan li-banī Isrā' ìla / wa-ŷa 'alnā min-hum a 'immatan yahdūna bi-amrin-nā (le dimos a Moisés el Libro, así que no te suscite duda encontrarte con él; lo constituimos en guía para los hijos de Israel / y de ellos hicimos maestros que guían por nuestra disposición).

wa-ŷa 'alnā-hum a'imma yahdūna bi-amri-nā (e hicimos de ellos maestros y guías por nuestra disposición).

Estas palabras están en el mismo núcleo del discurso de legitimación almohade e incluyen algunas de las claves de las monedas que los Mu'miníes acuñaron; pues en éstas se habla de la disposición (amr) de Dios, así como de la guía (hudà), procedente de Éste y que es ejercida por el imam o maestro (imām). Pues bien, el discurso almohade, basado precisamente en estos conceptos, muestra un punto flaco en cuanto a la ausencia del imam después de la muerte de Ibn Tūmart. En efecto, si en las monedas almohades se califica a éste de «nuestro maestro» (imāmu-nā), o «maestro de la comunidad» (imām al-umma), el título no volvió a utilizarse para ninguno de los califas ${ }^{15}$, que ostentaron sólo el de amīr al-mu'minin (emir de los creyentes). En las páginas siguien-

12 Probablemente originada en $11 H \bar{u} d, 88$.

${ }^{13} \mathrm{Ibn}$ Abī Zar', al-Anīs al-muțrib bi-raẉ̣ al-qirțās fì ajbār mulūk al-Magrib wa-ta'rïj madinat Fās, Rabat, 1972, 216.

${ }^{14}$ Fierro, M., "El título de la crónica almohade de Ibn Șāḥib al-Ṣalāt", Al-Qanțara, XXIV, 2 (2003), 291-294.

15 Medina Gómez, A., Monedas hispano-musulmanas, Toledo, 1992, 405 y ss.

Al-Qanțara (AQ) XXVII 2, julio-diciembre 2006, pp. 477-527 ISSN 0211-3589 
tes nos proponemos comprobar cómo la tensión entre esos dos principios de legitimidad, el carismático y el dinástico, dejó huella en las monedas de los Mu'miníes, concebidas como portadoras de un mensaje oficial elaborado por las nuevas elites que gobernaron el Occidente islámico de la época. Naturalmente, nos moveremos en el ámbito de «the question of mediation between God and men», donde M. García-Arenal encuadra el estudio de los movimientos mahdistas islámicos ${ }^{16}$. Nuestras indagaciones nos llevarán a poner de relieve cierta errónea atribución de una moneda, a partir de la cual podría interpretarse que se califica de imam (maestro) a uno de los califas mu'miníes; a sacar a la luz ciertas emisiones en las que no se había reparado hasta el momento, y a proponer nuevas lecturas de ciertos epígrafes. Trataremos, pues, de combinar, el trabajo de campo, que hemos realizado durante los últimos cinco años, a partir de restos arqueológicos numismáticos, conservados tanto en colecciones públicas como privadas, con la labor interpretativa, a partir de diversas fuentes, para resolver algunos de los problemas de atribución que plantean las monedas del cuadrado, es decir las que responden a la que A. Prieto llamó «la reforma numismática almohade». Y comprobaremos que el texto del Corán es, por supuesto, la fuente absoluta a partir de la cual hay que entender las leyendas de estas monedas; todo ello, dentro de la indeterminación que caracteriza al modelo numismático almohade y postalmohade.

\section{Revolución almohade}

La violenta irrupción en la historia ${ }^{17}$ del teólogo, teórico del derecho y líder mesiánico Ibn Tūmart y su principal seguidor, el fundador de la dinastía mu'miní, 'Abd al-Mu'min bn. 'Alī, dio lugar a la que se ha llamado revolución almohade ${ }^{18}$, que entrañó cambios sustanciales

16 En su libro Messianism and Puritanical Reform: Mahdīs of the Muslim West, Leiden-Boston, 2006, 1. Lamentamos no haber podido servirnos más en detalle de este excelente trabajo, que apareció mientras revisábamos el último borrador del presente estudio.

17 Bosch Vilá, J., Los Almorávides, Tetuán, 1956, 201 y ss.; Huici Miranda, A., Historia política del imperio almohade; Viguera, M. J., "Narrar la violencia: pasajes de la crónica de Ibn Șāhib al-Ṣalāt sobre los almohades", De muerte violenta: política, religión $y$ violencia en al-Andalus, ed. M. Fierro, Madrid, 2004, 301-319.

18 Fierro, M., "Spiritual alienation and political activism: the gurabä' in al-Andalus during the sixth/twelfth century" Arabica, XLVII (2000), 230-260, 230; Urvoy, D., Averroes, 77; Yabri, M.Á., El legado filosófico árabe: Alfarabi, Avicena, Avempace, Averroes, Abenjaldún, Feria García, M. C. (trad.), Madrid, 2001.

Al-Qanțara (AQ) XXVII 2, julio-diciembre 2006, pp. 477-527 ISSN 0211-3589 
en muchos aspectos del Occidente islámico ${ }^{19}$, comenzando por la ruptura con el referente espiritual y cultural de Bagdad, como ya señaló C. M. del Rivero ${ }^{20}$, al hablar de «emancipación del Califato de Oriente». Dicha revolución tuvo, entre sus emblemas más llamativos, el dírham cuadrado, que podemos situar en el marco de la «estética nueva y fácilmente reconocible» de que habla P. Cressier ${ }^{21}$, justificándolo en la voluntad, por parte de las autoridades almohades, de «difundir eficazmente su mensaje religioso y político». Del dírham se acuñaron cantidades ingentes, dentro de un sistema numismático de dos metales, como era canónico ${ }^{22}$, el cual sufrió una profunda reforma en todos sus aspectos ${ }^{23}$. Recordemos ${ }^{24}$ que los dírhams

${ }^{19}$ Cf., para transformaciones de orden material, Malpica Cuello, A., "La época almohade en Granada a partir de la arqueología", Los almohades: su patrimonio arquitectónico y arqueológico en el sur de al-Andalus, Valor Piechotta, M., Villar Iglesias, J. L. y Ramírez del Río, J. (eds.), Sevilla, 2004, 131-144.

20 "El arte monetario en la España musulmana: ensayo de tipología numismática", Revista de Archivos, Bibliotecas y Museos, LIV (1948), 51-72, 17.

${ }^{21}$ Cressier, P., "El patrimonio almohade de Almería", Los almohades: su patrimonio, 91-102, 93.

${ }^{22}$ Los dos metales son, desde luego, el oro y la plata. Decimos que sólo el sistema bimetálico es el canónico en la amonedación islámica, no porque el uso dejase siempre fuera las acuñaciones en cobre o bronce, sino porque el ordenamiento jurídico se limitaba a contemplar, como objetos canónicos, el dinar y el dírham; cf., entre las fuentes medievales, al-'Azafī, Abū 1-'Abbās, Ițbāt mā lays budd li-man arād al-wuqūf 'alà haquiqat al-dīnār wa-l-șā' wa-l-mudd, ed. M. al-Šarīf, Abu Dabi, 1999; al-Bāhilī, Abū Muhammad, "Maqādīr al-awzān wa-nusub al-šar'iyya min sikkat al-muwahhidīn bi-1-Andalus", ed. R. al-'Afāqī, Al-Dajā'ir, 3 (2000), 189-204; Ibn al-Ŷayyāb, Abū 1-Ṭāhir, Kitāb al-Taqrīb wa-l-taysīr li-ifādat al-mubtadi' bi-sinā'at misāhāt al-sutūh, ms. Escorial, n. ${ }^{\circ}$ 929 Derenbourg (fol. 9 y ss.); Mālik, Muwațta', ed. A. R. 'Armūš, Beirut, 1982, 162 y ss.; y, entre los estudios contemporáneos, Chalmeta Gendrón, P., "Moneda y fiscalidad en la España musulmana", Moneda y monedas en la Europa medieval (siglos XII-XV), Pamplona, 2000, 179-192, 180; Hofman Vannus, I., "Referencias literarias al dírham y al dinar en el Manuscrito de Ocaña”, Anaquel de Estudios Árabes, 15 (2004), 165-174; Vallvé, J., "Notas de metrología hispano-árabe, III: pesos y medidas", Al-Qanțara, V (1984), 147-167.

${ }^{23}$ Prieto y Vives, A., "La reforma numismática de los almohades", Miscelánea de estudios y textos árabes, Madrid, 1915, 11-114; Ben Romdhane, K., Les monnaies almohades: aspects idéologiques et économiques, Tesis doctoral, Universidad de París, 1978; Fontenla Ballesta, S., "La numismática almohade", I Jarique de estudios numismáticos hispano-árabes, Zaragoza, 1988, 67-88; Ša 'bān, 'A. R., "Al-iṣlāh al-naqdī al-muwaḥhidī”, Maŷallat Kulliyyat al-Ādāb wa-l- 'Ulūm al-Insāniyya (Ŷāmi'at Muhammad al-Jāmis, Rabat), 23 (1999), 139-177; al-Šarīf, M., "Tadqīqāt hawl al-maskūkāt al-muwaḥhidiyya”, en al-Sarīf, M., Al-Garb al-islāmī: nușūs dafinna wa-dirāsāt, Tetuán 1999², 93-101; Vega Martín, M., Peña Martín, S. y Feria García, M. C., El mensaje de las monedas.

${ }^{24} \mathrm{Cf}$. Bel, A., "Contribution à l'étude des dirhems de l'époque almohade d'après un groupe important de ces monnaies, récemment découvert à Tlemcen", Hespéris, XVI

Al-Qanțara (AQ) XXVII 2, julio-diciembre 2006, pp. 477-527 ISSN 0211-3589 
mu'miníes cuadrados ${ }^{25}$ mostraban en su anverso la esencia de la teología almohade en tres frases que desarrollaban una metafísica monoteísta; entre ellas destacaba, con arreglo a lo antes dicho, y por su importancia ideológica específica para los almohades, la segunda, con mención del término amr (disposición) ${ }^{26}$, donde, como ya sabemos, se concentraba el discurso de legitimación mu'miní ${ }^{27}$; en tanto que en el reverso continuaba el ideario religioso de Ibn Tūmart, con una procesión de los tres seres sagrados: Dios, Muhammad y él mismo, el Mahdī, como líder mesiánico (Figura $1{ }^{28}$ ):

FIGURA 1.-Dírham almohade, con mención del Mahdi
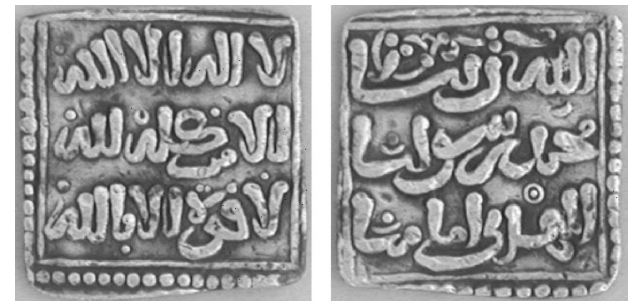

(1933), 1-68; Peña Martín, S. y Vega Martín, M., “¿Hasta cuándo perduró el modelo de la Antigüedad en las monedas andalusíes?", Chaves Tristán, F. y García Fernández, F. J. (eds.), Moneta qua scripta: la moneda como soporte de la escritura, Sevilla, 2004, 91-97; Prieto y Vives, A., "La reforma numismática"; Vega Martín, M. y Peña Martín, S., "El hallazgo de monedas almohades de Priego de Córdoba: aspectos ideológicos", Antiquitas, 15 (2003), 73-78; Vega Martín, M., Peña Martín, S. y Feria García, M. C., El mensaje de las monedas, y "La doctrina almohade a través de la numismática", Los almohades: problemas y perspectivas, Cressier, P., Fierro, M. y Molina, L. (eds.), Madrid, 2005, II, 1013-1049.

${ }_{25}$ Vives y Escudero, A., Monedas de las dinastías arábigo-españolas, Madrid, 1893 n. $^{\text {. }} 2088$ etc.; Hazard, H. W., The Numismatic History of Late Medieval North Afri$c a$, Nueva York, $1952, \mathrm{n}^{\circ} 1085$ etc.

26 De Corán 3, $\bar{A} l$ 'Imrān, 154. Sobre el uso de esta cita coránica en la epigrafía ajena a las monedas, Martínez Núñez, M. A., "Ideología y epigrafía almohades", Los Almohades: problemas y perspectivas, I, 5-52, 9.

${ }^{27}$ Cf. Fierro, M., "El título de la crónica"; Peña Martín, S. y Vega Martín, M., "La muerte dada en el Corán (glosario y estudio de una inscripción numismática de los Banū Gāniya)", De muerte violenta, 249-299; Vega Martín, M., Peña Martín, S. y Feria García, M. C., El mensaje de las monedas. cular.

28 Anverso y reverso de dírham almohade; 1,5 g., 14,2 × 14,4 mm.; colección parti-

Al-Qanțara (AQ) XXVII 2, julio-diciembre 2006, pp. 477-527 ISSN 0211-3589 
I.C

Lā ilāh illā Allāh

Al-amr kullu-h li-[A]llāh

Là quwwa illā bi-[A]llāh

(No hay divinidad sino Dios La disposición toda es de Dios Sólo hay fuerza por Dios)
II.C

Allāh rabbu-nā Muhammad rasūlu-nā al-Mahdī imāmu-nā

(Dios, nuestro amo

Muhammad, nuestro enviado El Mahdī, nuestro maestro)

Podemos, pues, considerar estas monedas, en su sencillez y limitación de medios, obras propias de un maestro en la elaboración de mensajes religiosos, por lo mucho que dicen e implican. Sin tratar de agotar el significado y sentido del dírham almohade mu'miní, en esta su versión inicial y más sencilla en la que no se menciona lugar de acuñación ${ }^{29}$, observemos que, en el anverso, se expone un conciso tratado sobre Dios, que sería fácilmente asumible desde las corrientes teológicas «apofáticas» o negativas ${ }^{30}$, en las que es fácil encuadrar a Ibn Tūmart ${ }^{31}$, y emanativas, pues, partiendo de una afirmación negativa sobre la divinidad, de la cual se afirma sólo su nombre («no hay divinidad sino Dios»), siguen dos afirmaciones de origen coránico que pueden entenderse desde una perspectiva metafísica y hacer alusión a las manifestaciones de Dios jerárquicamente enunciadas, o desde una perspectiva legitimadora, y aludir a la justificación divina de la empresa y actuación mu'miníes. Por su parte, el reverso ofrece una procesión jerárquica de tres seres: Dios, Muḥammad y el Mahdī, noción ésta (la designada como «Mahdī») de clara raíz carismática ${ }^{32}$,

29 Cf. Vega Martín, M. y Peña Martín, S., "Arcos y Cádiz en las monedas almohades (propuestas de lectura seguidas de una lista de cecas)", Al-Andalus-Magreb, XII (2005), 105-128.

${ }^{30}$ Teologías apofáticas o negativas son aquellas que no definen a Dios por sus atributos afirmativos, sino por la negación de cualquier atributo concebible por la razón humana; cf. Corbin, H., La paradoja del monoteísmo, Tabuyo, M. y López, A. (trad.), Madrid, 2003; Ratzinger, J., El espíritu de la liturgia: una introducción, Canas, R. (trad.), Salamanca, 2001, 145. De cualquier modo, la negatividad en la definición de los atributos del ser divino tiene algo de necesario, como mostró Otto, R., Lo santo: lo racional y lo irracional en la idea de Dios, trad. Vela, F., Madrid, 1980, 22 y 53 y ss., especialmente.

31 Cf. sus ideas sobre Dios en $A$ 'azz mā yuțlab, ed. 'A. G. Abū l-'Azm, Rabat, 1997, 224-226.

32 Sobre la noción de "mahdī" en la teología almohade, cf., entre lo mucho que se ha escrito, Fierro, M., "Le mahdī Ibn Tūmart et al-Andalus: l'élaboration de la légitimité almohade", Revue des Mondes Musulmans et de la Méditerranée, 91-94 (2001), 107-124, Rubio, O. S. A., L., El “ocasionalismo” de los teólogos especulativos del islam, San Lo- 
dispuestos gráficamente en una pirámide que implica la idea de tiempo, probablemente cíclico ${ }^{33}$, y sugiere modelos chíes, con la tríada Dios-Muhammad-'Alī, a partir de las monedas fatimíes, en las cuales ${ }^{34}$, en lugar del Mahdī, se mencionaba al imam 'Alī b. Abī Ṭālib, a quien se califica de «amigo de Dios»: 'Alī wali [A]llāh ${ }^{35}$. Todo ello, además, inscrito en una forma muy llamativa, que marca la ruptura con los tiempos de corrupción de la Comunidad contra la que Ibn Tūmart decía alzarse ${ }^{36}$. A un ciclo nuevo había de corresponder una forma nueva; idea que ya puso de manifiesto T. Burckhardt ${ }^{37}$ para explicar el cuadrado de las monedas almohades; y que está en consonancia con el sistema de proporcionalidades 38 entre los distintos ni-

renzo de El Escorial, 1987, 206 y ss., y, en este mismo volumen, Fierro, M., "Sobre monedas de época almohade".

33 Sobre la concepción circular del tiempo en la religiosidad tradicional, Eliade, M., Lo sagrado y lo profano, Gil Fernández, L. (trad.), Madrid, 1967, 82 y ss.; y sobre la teología cíclica de ciertas corrientes islámicas, Corbin, H., Tiempo cíclico y gnosis ismailí, Tabuyo, M. y López, A. (trad.), Madrid, 2003. La concepción cíclica no es sólo propia de los sistemas emanatistas cercanos al neoplatonismo, sino también de la tradición estoica (cf. Los estoicos antiguos, trad. Cappelletti, Á. J., Madrid, 1996, 82 y ss.); de ahí que se encuentre en la metafísica de pensadores no emparentados con el esoterismo ni la gnosis, tales como el contemporáneo de Ibn Tūmart, Ibn al-Sīd al-Bațalyawsī (cf. Peña Martín, S., "Gramática y verdad: tiempo y tiempo verbal según Ibn al-Sīd", Anaquel de Estudios Arabes, 17 (2006), 203-220). Y cf. Goodman, L. E., Islamic Humanism, Oxford-Nueva York, 2003, 209 y ss.

34 Al-'Ầȳābī, H.., Ŷāmi ‘ al-maskūkāt al- 'arabiyya bi-Ifrīqiya, Túnez, 1988; Farrugia de Candia, J., "Monnaies fatimites du Musée du Bardo", Revue Tunisienne, N. S. 1936, 333-372; 1937, 89-136, y 1948, 103-129; Miles, G. C., Fațimid Coins in the Collection of the University Museum, Philadelphia, and the American Numismatic Society, Nueva York, 1951. En las monedas fatimíes, como bien se sabe, la doble confesión referida a Dios y a Su enviado Muhammad se completa con la declaración 'Alī walī Allāh ('Alī es el amigo de Dios), que reaparece (bajo diversas reformulaciones) en monedas de los almorávides, siendo ahora el designado, no el imam 'Alī ibn Abī Ṭālib, sino el emir 'Alī ibn Yūsuf (cf. Peña Martín, S. y Vega Martín, M., "Rebuilding the contexts of the Andalusi epigraphic legacy: "The Friend of God" in Almoravid numismatic discourse", TRANS: Revista de traductología, 10 (2006), 73-83).

35 Sobre las nociones de wilāya (amistad, alianza, cercanía) y de wali Allāh (amigo de Dios) desde distintas perspectivas, Corbin, H., El imam oculto, López, A. y Tabuyo, M. (trad.), 2005, y La imaginación creadora en el sufismo de Ibn 'Arabi, Tabuyo, M. y López, A. (trad.), Barcelona, 1993, 29 y ss.; al-Sadr, M. B., Baht hawl al-wilāya, Kuwait, 1977; Sánchez Sandoval, J. J., Sufismo y poder en Marruecos, Cádiz, 2004; Waines, D., El islam, 176 y ss.

36 Cf. Fierro, M., "Spiritual alienation".

37 La civilización hispano-árabe, trad. Kuhne Brabant, R., Madrid, 1997, 177.

38 Se trata de la noción de nisba (relación), uno de los fundamentos del ideario de los Ijwān al-Ṣafā' (cf. Rasā'il, ed. B. al-Bustānī, Beirut, 1982), y de su correlato mīzān (balanza) en la gnosis chií (cf. Corbin, H., Templo y contemplación, pas.).

Al-Qanțara (AQ) XXVII 2, julio-diciembre 2006, pp. 477-527 ISSN 0211-3589 
veles del cosmos, que caracteriza al pensamiento tradicional. Y la nueva forma escogida fue el cuadrado, símbolo de gran virtualidad ${ }^{39}$, pues coincide con la que adoptaron los ejemplares del Corán durante el período almohade ${ }^{40}$, así como con las enseñas guerreras de los Mu'miníes ${ }^{41}$, desde la perspectiva histórica. Pero hay más. El cuadrado puede considerarse una alusión al cubo de la Ka'ba, centro del universo a partir del cual se trazan las cuatro direcciones ${ }^{42}$, y asimismo al propio número cuatro, que está en la base de la metafísica islámica al menos desde los Ijwān al-Șafā' ${ }^{43}$. Y, desde luego, con esto no agotamos la virtualidad simbólica del cuadrado almohade.

\section{Palabras medidas}

Para dejar bien asentada una de las bases de nuestro razonamiento posterior, el cual incluye consideraciones sobre el uso de las palabras y de sus valores más sutiles, nos importa destacar aquí que las elites del movimiento almohade tenían, como es lógico, amplios y profundos conocimientos de la lengua árabe y sus textos fundacionales. Decimos esto porque, en la historiografía contemporánea, se ha dudado de dichos conocimientos entre los artífices del mensaje epigráfico almohade, lo cual habría sido sorprendente, habida cuenta de que el fundador del movimiento, Ibn Tūmart, fue un alfaquí destacado, que completó su formación en la escuela Nizāamiyya de Bagdad ${ }^{44}$, y autor de un libro ${ }^{45}$ en que dejó muestras evidentes no sólo de su dominio absoluto de la

${ }^{39}$ Cf. Cirlot, J. E., Diccionario de símbolos, s.v.

40 Barrucand, M., "Observaciones sobre las iluminaciones de Coranes hispano-magrebíes", Arte islámico en Granada, ed. J. Bermúdez López, Granada, 1995, 165-171, y "Les enluminures de l'époque almohade: frontispices et 'unwān-s", Los almohades: problemas y perspectivas, I, 71-121.

${ }^{41}$ Pérez Higuera, M. T., "El arte", El retroceso territorial de al-Andalus: Almorávides y Almohades, siglos XI al- XIII, ed. M. J. Viguera Molíns, Madrid, 1997, 635-699, 686. Debemos a Maribel Fierro esta noticia y referencia.

${ }^{42}$ Cf. al-Garnāti, Abū Hāmid, Al-Mu'rib 'an ba'd 'aŷẩib al-Magrib, ed. y trad I. Bejarano, Madrid, 1991, 231 y ss. (texto castellano).

${ }^{43}$ Rasà'il, pas.

${ }^{44}$ Sobre su viaje a Oriente, cf., por ejemplo, Huici Miranda, A., Historia política, 28 y ss.; y, sobre su relación con la mencionada escuela, Griffel, F., "Ibn Tūmart's rational proof for God's existente and his unity, and his connection to the Nizāmiyya madrasa in Bağdād", Los almohades: problemas y perspectivas, II, 753-813.

45 A'azz mā yutlab. 
lengua árabe, como era de esperar en un profundo conocedor de los textos sagrados del islam, sino, además, de lingüística y hermenéutica $^{46}$. Nos consta, por otro lado, que del cuerpo orgánico de intelectuales almohades formaron parte gramáticos, como Ibn Mad̄ā', y que los califas mu'miníes pusieron mucho cuidado en la formación lingüística de sus hijos, procurándoles como preceptores a los más destacados lingüistas de su tiempo ${ }^{47}$. Pues bien, a pesar de ello, un destacado estudioso de las monedas almohades, S. Fontenla Ballesta, autor de valiosos trabajos especializados ${ }^{48}$, y para argumentar a favor de la hipótesis de que los Mu'miníes siguieron modelos establecidos por Ibn Qasī, el líder religioso y político del Algarve ${ }^{49}$, se ha hecho eco de la opinión de algunos otros investigadores ${ }^{50}$ que pusieron en tela de juicio los conocimientos de árabe y de teología de las elites almohades ${ }^{51}$ :

${ }^{46}$ Cf. Peña Martín, S., "Hermenéutica y gramática bajo los almohades: Ibn Jarūf y los testimonios tardíos", Al-Qantara, XXVI, 2 (2005), 371-380.

${ }^{47}$ Cf. Vega Martín, M. y Peña Martín, S., "El nombre de Priego en una moneda almohade", Antiqvitas, 17 (2005), 143-147.

48 Entre otros, "La numismática almohade"; "Notas sobre metrología almohade", Gaceta Numismática, 150 (2003), 29-30; "Numismática y propaganda almohade", Al-Qanțara, XVIII, 2 (1997), 447-462, o "Especificidad de la moneda almohade", Los Almohades: problemas y perspectivas, I, 53-69.

49 Que sepamos, la idea de que los Almohades siguieron el modelo de Ibn Qasī parte de Vives, A., "Indicación del valor en las monedas arábigo-españolas", Estudios de erudición oriental: homenaje á D. Francisco Codera en su jubilación del profesorado, ed. E. Saavedra, Zaragoza, 1904, 513-522, 520. Y cf., acerca de Ibn Qasī en general y de sus monedas, Borges, A. G. M., Ibn Qasi, rei de Mértola e mahdi luso-muçulmano, Mértola, 2003; Fierro, M., "Doctrinas y movimientos de tipo mesiánico en al-Andalus", IX Semana de Estudios Medievales: Milenarismos y milenaristas en la Europa medieval, Nájera, 1999, 159-175, 170 y ss., y “Opposition to Sufism in al-Andalus", De Jong, F. y Radtke, B. (eds.), Islamic Mysticism Contested: Thirteen centuries of controversies and polemics, Leiden-Boston-Colonia, 174-206, 188 y ss.; Kassis, H. E., "La moneda, pesos y medidas", Ariza, A. (trad.), El retroceso territorial, 301-327, 322, y "Les taifas almoravides", II Jarique de numismàtica hispano-àrab, Lleida, 1990, 51-91, 56 y ss.; Marín, M., “À l'extrémité de l'Islam médiéval: élites urbaines et islamisation en Algarve", Annales: Histoire, Sciences Sociales, 2 (1998), 361-381; Marinho, J. R., "Moedas de Ahmad ibn Qasī batidas en Silves", O Arqueólogo Portugués IV, 3 (1985), 177-196, y "The beginning of the characteristic Almohad coinage: some hypotheses", Proceedings of the $10^{\text {th }}$ International Congress of Numismatics, ed. I.A. Carradice, Londres, 1986, 430-435.

${ }^{50}$ Marinho, J. R., Moedas musulmanas de Beja e Silves. Um achado monetário no Concelho de Sesimbra, Sesimbra, 1968, y Sidarus, A., "Novos dados sobre Ibn Qasi de Silves e as taifas almorávides no Gharb al-Andalus", I Jornadas de Silves, Actas. Silves (3 e 4 de Setembro 1992), Silves, 1992, 35-40; cf., al respecto, Fierro, M., "Le mahdī Ibn Tümart", n. 8.

51 Fontenla Ballesta, S., "Las primeras acuñaciones almohades", Nvmisma, 244 (2000), 53-59, 55.

Al-Qanțara (AQ) XXVII 2, julio-diciembre 2006, pp. 477-527 ISSN 0211-3589 
El hecho de que las monedas de Ibn Qasī recogieran la versión gramaticalmente más correcta, Muhammad nabiyyunā (Muhammad es nuestro profeta), que la de Muhammad rasūlunā (Muhammad es nuestro enviado) que consta en los dirhemes almohades, puesto que es enviado de Dios, puede indicar un intento de rectificar gramatical y religiosamente las leyendas almohades ya prexistentes [...].

Ahora bien, un movimiento como el almohade tuvo que manejar más que con soltura los rudimentos lingüísticos y textuales sobre los que basó su discurso de legitimación. Y, en consecuencia, solamente puede concebirse que quienes diseñaron las monedas mu'miníes conocían, y en gran profundidad, la gramática del árabe y los principios del islam. La observación de S. Fontenla podría basarse en un juicio sobre la gramática del árabe hecho desde la percepción de un hablante del español. El sintagma de anexión nominal árabe ${ }^{52}$, como es el caso de rasūlu-nā («enviado de nosotros», nuestro enviado), en Muhammad rasūlu-nā (Muhammad es nuestro enviado), es una estructura lo bastante indeterminada semánticamente como para admitir distintas relaciones entre los referentes de sus dos elementos. Y, desde luego, su gramaticalidad no puede juzgarse a partir de su traducción a otra lengua, y menos a una, donde, en contraste con lo que ocurre en árabe, sí existen los posesivos (como en nuestro enviado). Por más que también en español el sintagma equivalente, el grupo nominal constituido por un núcleo y un adyacente precedido de la preposición de (como en el enviado de los musulmanes) es igualmente indeterminado ${ }^{53}$; de manera que no es extraño, tampoco en el ámbito de las lenguas romances, el que la determinación de un nombre por otro, aunque aquí no sea por medio del caso genitivo sino por la preposición $d e$, sirva para relaciones subjetivas u objetivas. $\mathrm{Y}$ es, en efecto, bien conocido que en latín se registran genitivos tanto de la variedad subjetiva como de la objetiva ${ }^{54}$. O sea, que volviendo a nuestro ejemplo

52 Cf. Blachère, R. y Gaudefroy-Demombynes, M., Grammaire de l'arabe classique (morphologie et syntaxe), París, $1975^{3}, 322$ y ss.

${ }_{53}$ Alarcos Llorach, E., Gramática de la lengua española, Madrid, 1994, 220: "De igual modo, la preposición de enlaza un adyacente con el sustantivo nuclear de un grupo nominal, sin que sean pertinentes sus valores léxicos; es un simple índice de la dependencia del sustantivo adyacente respecto de su núcleo, y puede por tanto referirse a muy variadas relaciones reales entre los entes denotados".

${ }_{54}$ Bassols de Climent, M., Sintaxis latina, Madrid, 1956, I, 89: "El genitivo cuando depende de abstractos verbales puede asumir el papel de sujeto u objeto; así metus hostium "el temor que tienen los enemigos" (genitivo subjetivo) o "el temor que se tiene a los enemigos" (genitivo objetivo)".

Al-Qanțara (AQ) XXVII 2, julio-diciembre 2006, pp. 477-527 ISSN 0211-3589 
español, el enviado de los musulmanes no tiene que significar «el enviado por los musulmanes» necesariamente, sino que es concebible que se trate de un adyacente objetivo y que signifique «el enviado $a$ los musulmanes».

Sin embargo, todo esto sobra si tenemos en cuenta que la gramática del árabe funciona con arreglo a sí misma y no a las traducciones que de textos árabes se hagan a otras lenguas, y que los usos lingüísticos árabes han de ser remitidos no a nuestras impresiones, sino a las fuentes árabes. Esto es lo importante, ya que la declaración de las monedas almohades: Muhammad rasülu-nā (Muhammad es nuestro enviado) deriva, por un lado, de concepciones religiosas islámicas y, por otro, de una base textual de autoridad absoluta: el Corán. En primer lugar, y volviendo a la selección del término rasūl (enviado, apóstol) frente a $n a b \bar{\imath}$ (profeta), recordemos que desde la perspectiva islámica $^{55}$ (o desde la cristiana, por cierto) no es indiferente hablar de nabi (profeta) o de rasūl (apóstol, enviado). No son sinónimos, sino que entrañan diferencias teológicas. De manera que cuando en las monedas almohades se pasó de nabī a rasūl para calificar a Muḥammad no se estaba corrigiendo gramaticalmente o religiosamente una expresión desafortunada, sino recurriendo a una u otra de dos verdades concomitantes de la fe islámica. Desde ésta, ambas cosas, que Muhammad fuera profeta y que fuera enviado pueden afirmarse con razón, pero no se está diciendo lo mismo en cada caso. Y, desde luego, los teólogos almohades conocían bien esto, empezando por el propio Ibn Tūmart, quien en una de sus cartas califica a Muhammad de «profeta y enviado» de Dios ${ }^{56}$; o bien, antes que él, por Ibn Hazm ${ }^{57}$, para quien la profecía (nubuwwa) consiste en que Dios concedió a algunas personas unos determinados conocimientos, en tanto que la misión (risāla) entraña algo más: el que Dios ordene al profeta la transmisión de $\mathrm{Su}$ aviso. Las razones últimas de ese sutil cambio de nabī (profeta) a rasūl (enviado, apóstol) en las monedas se nos siguen escapando, al menos en gran parte, en nuestro estado de conocimientos, pero lo que

${ }^{55}$ Cf., por ejemplo, Corbin, H., Templo y contemplación, 70 y ss.

56 Documents inédits, 8 (texto árabe): "[...] fa-innā naḥmadu ilay-kumu [A]llāha lladị lā ilāha illā Huwa wa-naškuru-hu 'alà âlā'i-hi wa-ni'ami-hi, wa-nuṣallī 'alà Muhammadin nabiyyi-Hi wa-rasūli-Hi [...]”.

57 Rasā'il, ed. I. 'Abbās, Beirut, 1983, IV, 414. 
es seguro es que no se trata de una suerte de enmienda por motivos de desconocimiento gramatical o religioso.

Muy por el contrario, como hemos dicho, la frase deriva del propio Corán, y es necesario partir del Corán para entenderla. M. A. Martínez Núñez ha recalcado el «predominio» del Libro sagrado en la epigrafía monumental almohade, hasta el punto de que se puede afirmar que el Corán es el «texto preferente» en la constitución del discurso epigráfico almohade ${ }^{58}$. Como vemos, en las monedas ocurre otro tanto. En efecto, el Corán incluye múltiples pasajes en los que se subraya que cada uno de los enviados de Dios pertenece al pueblo al que transmiten el mensaje divino; que son uno de ellos, uno del pueblo al que se envían. La lectura del Libro Sagrado no deja dudas al respecto, como se comprueba, sobre todo, en los pasajes donde rasūl (enviado) aparece en estado de anexión con algún pronombre personal, igual que en las monedas almohades; como ocurre en el siguiente ${ }^{59}$ (9 al-Tawba, 70):

atat-hum rusulu-hum bi-l-bayyināti (sus [de ellos] enviados les trajeron las pruebas elocuentes)

El mismo ideograma: que los receptores del Mensaje reciben a un emisario que es de ellos mismos, se expresa también en el Corán por otro procedimiento sintáctico diferente, en el interviene la preposición $\min$ (de), cuyo sentido de procedencia en árabe no deja ninguna duda en cuanto a lo que decimos, por ejemplo ${ }^{60}$ ( 2 al-Baqara, 151$)$ :

arsalnā fi-kum rasūlan min-kum (os hemos mandado un enviado de entre vosotros).

El que se trate de un emisario del mismo grupo de los destinatarios del mensaje, tiene dos aspectos. Por un lado, el Corán deja bien claro que el enviado tiene un carácter humano, no sobrenatural; de ahí que se comporte como todos los receptores del mensaje, por ejemplo ${ }^{61}$,

58 "Ideología y epigrafía", 21 y 24.

59 Asimismo, 14 Ibrāhìm, 9-12, 40; 7 Al-A 'räf, 101; 30 Al-Rūm, 9; 35 Fäțir, 25; 40 Gäfir, 22 y 50; 64 Al-Tagābun, 6; 10 Yünus, 13; 40 Gäfir, 83; 23 Al-Mu'minīn, 44; 40 Gäfir, 5.

60 Asimismo, 3 Āl 'Imrān, 164; 7 Al-A 'räf, 35

${ }^{61}$ Asimismo, 7 Al-A 'räf, 63; 25 Al-Furqān, 20. 
cuando Dios le da a Muhammad la orden siguiente (18 Al-Kahf, 110, y 41 Fușsilat, 6):

qul innamā anā bašarun mițlu-kum (di: yo soy un ser humano como vosotros).

Pero, por otro, y además de la naturaleza humana del enviado, se subraya su pertenencia a una comunidad concreta, a la que se dirige en su lengua ${ }^{62}$; así, Muḥammad es enviado a los árabes; como se manifiesta ${ }^{63}$, en el pasaje siguiente (14 Ibrāhìm, 4):

wa-mā arsalnā min rasūlin illā bi-lisāni qawmi-hi (sólo hemos enviado mensajeros en la lengua de sus pueblos).

Es de gran importancia para nosotros recalcar este modelo de guía de la comunidad que pertenece a ella, pues pudo fundamentar, acaso por analogía, el papel de un bereber como Ibn Tūmart al frente de los pueblos del Magreb ${ }^{64}$. Por otra parte, es necesario tener también en cuenta, por los motivos que veremos enseguida, un nuevo pasaje coránico, donde se solicita a Dios que conceda maestros o imames adecuados para los prevenidos o temerosos de Dios (25 Al-Furqān, 74-75):

wa-ŷa 'alnā li-l-muttaqīna imāman (constitúyenos a un maestro para los prevenidos).

\section{Una cita inadvertida}

La falta de consideración de los modelos coránicos es probablemente lo que ha motivado una lectura errónea de otro de los epígrafes numismáticos almohades; en concreto, el que aparece en uno de los lados del cuarto de dírham ${ }^{65}$, una de las fracciones de éste, también cuadrada ${ }^{66}$, cuya leyenda es (Figura $2^{67}$ ):

62 De ahí que, según recoge al-Ŷāhiz (al-Bayān wa-l-tabyīn, ed. 'A. S. M. Hārūn, El Cairo, 1975, III, 291), haya quienes han sostenido que Dios le inspiró (ilhām) a Ismā‘īl la lengua árabe, para que fuese conocedor del habla del pueblo al que era enviado.

63 Asimismo, 10 Yünus, 47; 62 al-Ŷити' $a, 2$.

${ }^{64}$ Cf. Hamès, C., "Le pouvoir dynastique almohade entre parenté berbère, arabe et islamique", Los Almohades: problemas y perspectivas, II, 425-450.

65 Medina Gómez, A., Monedas hispano-musulmanas, 437.

${ }^{66}$ Con unos 9 milímetros de lado, y entre 0,3 y 0,4 gramos de peso.

67 Cuartos de dírham almohades, procedentes del hallazgo de Priego de Córdoba; Museo Arqueológico y Etnológico de Córdoba.

Al-Qanțara (AQ) XXVII 2, julio-diciembre 2006, pp. 477-527 ISSN 0211-3589 
Figura 2.-Anversos y reversos de seis cuartos de dírham almohades

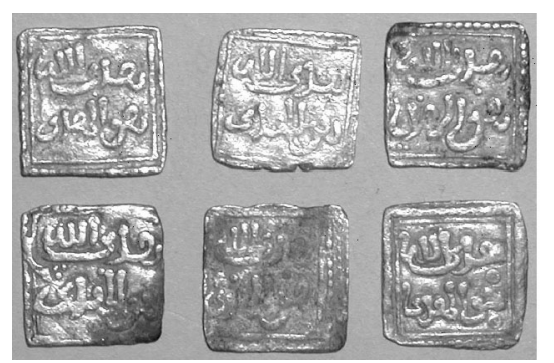

I.C

Hudà [A]llāh huwa l-hudà

(La Guía de Dios es la buena guía)

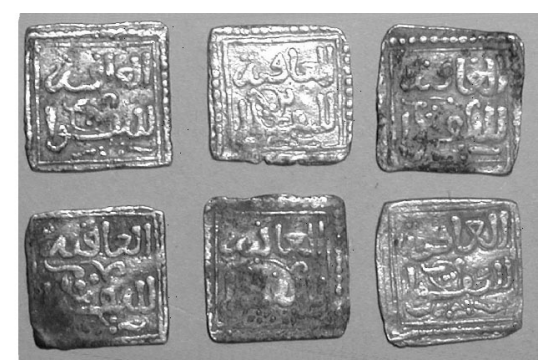

II.C

Al- 'āqiba li-l-taqwā

(Tiene desenlace la prevención)

Pues bien, si la leyenda del anverso (Hudà [A]llāh huwa l-hudà), que es una cita textual del Corán (2 al-Baqara, 120, y 3 Al'Imrān, 73), no ha planteado problemas a los investigadores, y se ha transcrito como acabamos de indicar; con la inscripción del reverso ha ocurrido algo diferente. Antes de entrar en ello, recordemos que la atribución a los Mu'miníes de este cuarto de dírham cuadrado, con los epígrafes indicados, no ha estado siempre clara. Más bien al contrario, pues A. Vives ${ }^{68}$ la incluyó en su corpus entre las monedas nazaríes, junto con otra, exactamente igual, pero diseñada de tal manera que, completando el cuadrado con cuatro sectores decorados, formaba un círculo. Naturalmente, esta adición suponía un aumento de peso, y, mientras el cuarto cuadrado pesaba en torno a 0,4 gramos, esta otra, circular, tenía el peso del medio dírham, en torno a los 0,7 gramos. Volveremos más abajo a esta moneda redondeada, cuando tengamos datos suficientes para emitir una hipótesis acerca de su atribución. Por ahora quedémonos con los textos de la leyenda del reverso, que A. Vives interpretó de modo extraño, pues transcribió: *Al-'áfiya li-l-muttaqū (La salud es de los prevenidos ${ }^{69}$ ), frase gramaticalmente incorrecta y

${ }^{68}$ Monedas de las dinastías, n. ${ }^{\text {ss }} 2209$ y 2210.

69 Estas traducciones que damos entre paréntesis son nuestras; A. Vives no facilitaba versiones de los epígrafes numismáticos.

Al-Qanțara (AQ) XXVII 2, julio-diciembre 2006, pp. 477-527 ISSN 0211-3589 
alejada de su original coránico. Sin embargo, el gran numísmata decimonónico, más adelante, en el mismo libro, y al ofrecer el índice de inscripciones ${ }^{70}$, se desdijo en lo que respecta a la primera palabra: al- 'āqiba (el desenlace), pues ahora transcribía *Al- 'āqiba li-l-muttaqu (El desenlace es de los prevenidos), junto con una suerte de versión corregida gramaticalmente, pero aún desajustada con el original coránico: Al- 'áqiba li-l-muttaqin (El desenlace es de los prevenidos).

Por la época en que A. Vives publicó su corpus, J. D. de la Rada dio a la luz su catálogo de monedas árabes en el Museo Arqueológico de Madrid ${ }^{71}$, donde volvía a presentar las dos mismas monedas, el cuarto cuadrado y la redonda del peso doble, ambas con las inscripciones coránicas que hemos recogido, y una lectura coincidente con la del índice — esto es, no la del catálogo - de A. Vives, pues, J. D. de la Rada, transcribía *Al- 'āqiba li-l-muttaqū (El desenlace es de los prevenidos). Pero, eso sí, seguía atribuyéndolas ambas a los Nazaríes. La razón de esto último, y ya que en las piezas no hay ningún signo directo ni indirecto que señale a los Banū l-Aḥmar, es probablemente la dependencia de ambos numísmatas de cierto texto de Ibn al-Jatịib ${ }^{72}$, donde éste enumera, por sus inscripciones y pesos, las monedas emitidas por los Nazaríes, y entre ellas incluye una fracción con las inscripciones indicadas, en este caso, bien transcritas, como es lógico (Hudā [A]llāh huwa l-hudà y Al- 'ăqiba li-l-taqwà). Es difícil precisar cuál es la razón que llevó a Ibn al-Jatịib, que no tenía por qué ser un experto en historia numismática, a esta confusión. Tal vez se debió a que esa moneda almohade, el cuarto de dírham, siguió circulando durante largo tiempo en el emirato nazarí. Lo cierto es que se trata, al menos en su variante cuadrada, del cuarto de dírham almohade más usual. Esto puede afirmarse con rotundidad por dos razones, una arqueológica y la otra, epigráfica. En cuanto a la primera, basta comprobar la presencia abundante de tales piezas en el hallazgo de moneda almohade de plata de Priego de Córdoba que se conserva en el Museo Arqueológico y Etnológico de Córdoba ${ }^{73}$. La segunda razón, la epigráfica, es que hay monedas cua-

70 Vives, A., Monedas de las dinastías, 465.

71 Rada y Delgado, J. de D., Catálogo de las monedas arábigas españolas que se conservan en el Museo Arqueológico Nacional, Madrid, 1892 (n. ${ }^{\text {os }} 747$ y 748).

72 Al-Iḥạta fì ajbār Garnātă, ed. 'A.A. 'Inān, El Cairo, 1973, I, 137-138.

73 Carmona Ávila, R., Luna Osuna, D. y Moreno Rosa, A., Museo Histórico Municipal, Priego de Córdoba, 1998, 40-42; Marcos Pous, A. y Vicent Zaragoza, A. M., "Los tesorillos de moneda hispano-árabe del Museo Arqueológico de Córdoba”, III Jarique de 
dradas con esas leyendas y que incluyen nombres de ciudades, en las que no pudieron acuñar los Nazaríes, en concreto Córdoba y $\mathrm{Fez}^{74}$, como mínimo. El texto de Ibn al-Jațīb, con lo que es a todas luces una confusión, ha pasado después a otras fuentes secundarias más recientes ${ }^{75}$; si bien algunos córpora más especializados ya dejan fuera a estas monedas del sistema nazarí ${ }^{76}$.

Se trata, pues, de monedas mu'miníes, y las inscripciones de ambos lados que componen su leyenda, esto es, el anverso acerca de la guía de Dios y el reverso sobre el desenlace que espera a los prevenidos o temerosos de Dios, son perfectamente coherentes entre sí, siempre que tengamos una vez más en cuenta el palimpsesto coránico. Lo veremos de inmediato. Antes, recordemos que la leyenda del reverso, Al- 'āqiba li-l-taqwà (Tiene desenlace la prevención), se ha seguido interpretando mal durante las últimas décadas. Se han propuesto, así, varias lecturas, lejanas del original coránico. Tal vez la más cercana a la de A. Vives sea la transcripción $77 *$ Al-'äfiya li-l-taqwā (¿Hay salud para la prevención?); pero ha habido una segunda ${ }^{78}$, *Al-'áfiya al-muttaqū (¿La salud son los temerosos de Dios?); una tercera ${ }^{79},{ }^{*}$ Li-l- 'áfiya al-taqwā (¿La salud tiene temor de Dios?) y hasta una cuarta ${ }^{80}, *$ Al-'áfiya al-taqwā [«El bienestar

numismática hispano-árabe, Madrid, 1992, 206, y Vega Martín, M. y Peña Martín, S., "El hallazgo de monedas".

${ }^{74}$ Para estas dos cecas en dichas monedas, Medina Gómez, A., Monedas hispano-musulmanas, 437.

75 Tales como el mencionado y notable estudio de Vallvé Bermejo, J., "Notas de metrología", 160-161; el compendio sobre la plata nazarí de Fontenla Ballesta, S., "Un intento de sistematización de la plata nazarí", I Jarique de estudios, 141-144; el ensayo de metrología de Jiménez Puertas, M., "La evolución del sistema monetario nazarí", Gaceta Numismática, 150 (2003), 31-49, 47, o la visiones generales sobre la moneda nazarí, de Rodríguez Lorente, J. J. y Fontenla Ballesta, [F.] S., "Contribución al estudio de la metrología hispano-árabe: la plata nașrí”, Al-Qantara, IX, 2 (1988), 475-487; Rosselló Bordoy, G., "La moneda", El reino nazarí de Granada (1232-1492): política, instituciones; espacio y economía, ed. M. J. Viguera Molíns, Madrid, 2000, 565-582.

${ }^{76}$ Medina Gómez, A., Monedas hispano-musulmanas; Rodríguez Lorente, J. J., Numismática nașrí, Madrid, 1983.

77 Gaspariño García, S., "Algunas monedas almohades", Canto García, A. y Salvatierra Cuenca, V., IV Jarique de numismática andalusí, Jaén, 2001, 213-226, 214.

78 Fontenla Ballesta, S., "Un intento de sistematización", 144.

79 Rodríguez Lorente, J. J. y Ḥāfiz Ibrāhim, T., Numismática de Ceuta musulmana, Madrid, 1987, 111.

${ }^{80}$ Canto García, A. y Hāiziz Ibrāhīm, T., Moneda andalusí: la colección del Museo Casa de la Moneda, Madrid, 2004, 378; Medina Gómez, A., Monedas hispano-musulmanas, 437.

Al-Qanțara (AQ) XXVII 2, julio-diciembre 2006, pp. 477-527 ISSN 0211-3589 
(está en) la santidad» ${ }^{81}$. Todas ellas son más o menos agramaticales y siempre divergentes del original coránico. Acudamos de nuevo a éste. En primer lugar, como hemos apuntado, llama la atención la conexión intertextual ${ }^{82}$ entre la moneda en cuestión y el Discurso divino, ya que en éste aparecen unidas, en dos pasajes distintos (39 al-Zumar, 57, y 47 Muhammad, 17), las dos ideas expresadas en cada lado de la moneda:

law anna [A]llāha hadā-nī la-kuntu mina l-muttaqina (si Dios me hubiera guiado, yo me contaría entre los prevenidos).

wa-lladīna htadū zāda-hum hudan wa-atā-hum taqwā-hum (a los que están guiados Él les proporciona aún más guía y les da su prevención).

Yendo a las fuentes coránicas del epígrafe que hemos asignado al reverso (Al-'áqiba li-l-taqwà), dejemos claro que se trata de una cita textual $(20, T \bar{a} h \bar{a}, 132)$ :

wa-l- 'āqiba li-l-taqwà (tiene desenlace la prevención).

Y advirtamos que en el texto coránico aparecen algunas formulaciones algo diferentes de la misma idea, por ejemplo ${ }^{83}$, en (7 al-A 'räf, 128):

wa-l-'āqiba li-l-muttaqina (el desenlace es para los prevenidos).

El término taqwà había ya aparecido en las monedas acuñadas en el Magreb, en tiempos de los Idrisíes (segunda mitad del siglo II h./finales del VIII d. C.), formando parte de un epígrafe de sentido moral ${ }^{84}$; y se encuentra a menudo en la correspondencia dirigida por Ibn Tūmart ${ }^{85}$. Su presencia destacada en discursos islámicos no coránicos deriva del hecho de que la taqwà sea una de las recomendaciones que se dirigen a los musulmanes en sendos textos de primer

81 Esta versión es la que ofrece Medina Gómez, A.

82 Sobre intertextualidad, Kristeva, J., Semeiotike: recherches pour une sémanalyse, París, 1969

83 Y 11 Hūd, 49.

${ }^{84}$ Colin, G. S., "Monnaies de la période idrisite trouvées à Volubilis", Hespéris, 22 (1936), 113-125, 115. La fórmula es wa-l-taqwà barakatun mina [A]llāhi (y el temor es bendición de Dios).

85 Así, en cierta fórmula de clausura, al solicitar de Dios el temor o prevención (Documents inédits, 8).

Al-Qanțara (AQ) XXVII 2, julio-diciembre 2006, pp. 477-527 ISSN 0211-3589 
orden: un sermón (juṭba) de Muḥammad y un mensaje del califa «perfecto» 'Umar ibn al-Jattāa ${ }^{86}$. En cuanto a la noción que designa, podemos decir que se trata de un sentimiento o actitud en el fiel, y resulta extremadamente difícil de definir ${ }^{87}$. A menudo traducida por «temor de Dios», hemos optado por «prevención», aludiendo así al complejo de emociones que en la persona religiosa suscita la existencia del ser divino, según mostró R. Otto en su estudio sobre lo «numinoso» o irracional en la idea de Dios ${ }^{88}$. En cierto modo, podemos considerar que la taqwà, que los lexicógrafos árabes medievales - nuestra fuente - entendían como cercana a la prevención o la precaución ${ }^{89}$, y que también se traduce por «piedad», es una noción vinculada con la de isläm (sumisión), pues entraña una humillación de las criaturas ante Dios, que conduce, como veremos, a la salvación. La noción de taqwà y algunos derivados aparecen a menudo en el Corán, lo que nos permite situarla en el contexto argumentativo del que forma parte. En primer lugar, esa «prevención» es suscitada solamente por Dios y por Él ordenada, en múltiples pasajes ${ }^{90}$, como el siguiente (23 al-Mu'minin, 52):

wa-anā rabbu-kum fa-ttaqūnī (y yo soy vuestro Amo: preveníos de mí).

\section{La meta de la salvación}

Ahora bien, la prevención obtiene una recompensa de Dios, que dirige a quienes la experimentan un mensaje y una guía, como indican estas palabras ${ }^{91}$ (19 Maryam, 97):

fa-innamā yassarnā-hu bi-lisāni-ka li-tubaššira bi-hi l-muttaqīna (lo hemos puesto fácil [el Corán], en tu lengua, para que les des con él la buena nueva a los temerosos de Dios).

86 Al-Ŷāhiz, Al-Bayān wa-l-tabyīn, II, 31 y 46.

87 Cf. Waines, D., "Muslim piety and food of Gods", Al-Qanțara, XXI, 2 (2000), 411-424.

88 Otto, R., Lo santo, 21-48, especialmente.

89 Ibn Fāris, Mu 'ýam maqāyīs al-luga, ed. 'A. S. M. Hārūn, Beirut, 1991, VI, 131.

9016 al-Nahl, 2 y 52; 23 al-Mu'minin, 87; 16 al-Naḥl, 52; 22 al-Haŷŷy, 1; 26 al-Š́ 'arā' 108, 110, 126, 131, 132; 48 al-Fath, 26.

91 Y 16 al-Nahl, 128; 21 al-Anbiyà', 48-49.

Al-Qanțara (AQ) XXVII 2, julio-diciembre 2006, pp. 477-527 ISSN 0211-3589 
Y, en efecto, son múltiples los pasajes coránicos, como el siguiente ${ }^{92}$ (19 Maryam, 85), que confirman la salvación concedida por Dios a los prevenidos:

yawma naḥšuru l-muttaqīna ilà l-rahmāni wafdan / wa-nasūqu l-muŷrimīna ilà $\hat{Y}$ ahannama wirdan (el día en que reunamos a los temerosos de Dios en un cortejo hacia el Clemente / y llevemos a los criminales a abrevar en Gehenna).

Por otro lado, que los prevenidos obtendrán la Gloria (al-na 'ìm) está expresamente formulado en la poesía andalusí del tiempo de Ibn Tūmart ${ }^{93}$. Pero pasemos ahora al otro término que aparece en la moneda en contigüidad con al-taqwà (la prevención): al- 'àqiba, o su sinónimo al-'uqbà, que hemos traducido por «desenlace». Por tal hemos de entender el resultado, la consecuencia de algún hecho previo $\mathrm{y}$, por consiguiente, puede tratarse tanto de algo bueno como de algo malo. Es lógico, ya que los resultados del devenir pertenecen a Dios, como quedaba implicado en la declaración Al-amru kullu-hu li-[A]llāh (la disposición toda es de Dios) y explícito en otros pasajes coránicos (22 al-Haŷŷ, 41, y 31 Luqmān, 22):

li-[A]llāhi 'àqibatu l-umūri (de Dios es el desenlace de todos los asuntos).

Efecto de ello es que en el Corán se utiliza un término de la misma raíz, 'iqāb (castigo), para designar la retribución a quienes no se hayan prevenido de Dios ${ }^{94}$, y que en alguna ocasión el mismo 'āqiba sirva para hablar del castigo a quienes se alzan contra Él, por ejemplo, en el pasaje siguiente ${ }^{95}$ (28 Al-Qașas, 40):

kayfa kāna 'āqibatu l-zālimina (cuál fue el desenlace de los injustos).

Sin embargo, en el Discurso divino, 'āqiba (desenlace), o su variante ' $u q b a{ }^{96}$, suele ir asociado con el triunfo o el jardín paradisíaco

92 Y 19 Maryam, 72; 39 al-Zumar, 73; 43 al-Zujruf, 35; 54 al-Qamar, 54; 13 al-Ra'd, 35 y 42;47 Muhammad, 15; 77 al-Mursalāt, 41; 78 al-Naba', 31; 16 al-Nahll, 30-31; 25 al-Furqān, 15

93 Ibn al-Sīd al-Bațalyawsī habla, así, en uno de sus poemas religiosos de "na'īm al-atqiyā"”, o sea, la Giloria de los prevenidos (al-Maqqarī, Azhār al-riyād, eds. M. al-Saqqā, I. al-Abyārī, y 'A.H.. Šalabī, El Cairo, 1939-42, III, 135).

944 al-Mä'ida, 2: wa-ttaqū [A]llāha inna [A]llāha šadìda l- 'iqābi (y preveníos de Dios; Dios es duro en el castigo).

95 Y 16 al-Nahl, 36; 27 al-Naml, 14.

9613 al-Ra'd 24: fa-ni 'ma 'uqbà l-dāri (qué buen desenlace, la Casa).

Al-Qanțara (AQ) XXVII 2, julio-diciembre 2006, pp. 477-527 ISSN 0211-3589 
que se promete a los prevenidos; de modo que a veces la noción aparece junto a la de Mansión o Casa de que disfrutarán los justos en la otra vida (6 al-An' $\bar{a} m, 135$, y 28 al-Qașaș, 37):

fa-sawfa ta 'lamūna man takūn la-hu 'àqibatu l-dāri (y sabréis quién alcanzará el desenlace de la Casa).

Fuera del Corán, la asociación entre el paraíso y la prevención ante Dios se ha formulado de manera inequívoca; la hallamos, así, en uno de los Tratados de los Ijwān al-Ṣafā', donde se afirma que «el Jardín está ya preparado para los prevenidos» ${ }^{97}$. En conclusión, la doble leyenda del cuarto de dírham almohade: Hudà [A]llāh huwa l-hudà y Al- 'āqiba li-l-taqwà, constituye un claro mensaje escatológico, esto es, relativo al más allá. No fue ésta la vez primera en que las monedas islámicas del Occidente islámico hicieron algún tipo de alusión a la vida futura. M. Fierro ${ }^{98}$ ha mostrado cómo los iconos vegetales de las monedas acuñadas por los Omeyas de Córdoba en Madīnat al-Zahrā' son alusiones a los frutos del paraíso. Posteriormente, los Hammudíes acunaron monedas ${ }^{99}$ en las que se reproducía cierto pasaje coránico (3 $\bar{A} l$ 'Imrān, 85$)$ de claro contenido escatológico, que acabaría convirtiéndose, también con el precedente de los Zīríes de Qayrawān ${ }^{100}$, en uno de los rasgos distintivos de los dinares almorávides ${ }^{101}$ :

wa-man yabtagi gayra l-islām dīnan fa-lan yuqbala min-hu wa-huwa fì l-äjirati mina l-jāsirina (y quien aspire a otra ley que la sumisión [a Dios] hallará rechazo y estará en el otro mundo entre los fracasados).

Pero, por lo que hemos ido viendo, el mensaje más completo acerca de la vida futura, y en concreto acerca de la promesa de salvación para los prevenidos, se ofreció en las monedas almohades. Esta promesa se desarrolla con arreglo a la fuente absoluta del Corán y en concurrencia con la leyenda de las demás monedas almohades de plata, singularmente del dírham, según un esquema muy sencillo:

${ }^{97}$ Rasā'ill, ed. B. al-Bustān̄ī, Beirut, 1983, II, 376.

98 Fierro, M., "Madīnat al-Zahrā', el paraíso y los Fatimíes", Al-Qanțara, XXV, 2 (2004), 299-327.

${ }^{99}$ Prieto y Vives, A., Los reyes de Taifas: estudio histórico numismático de los musulmanes españoles en el siglo V de la hégira (XI de J. C.), Madrid, 1926, 173, n. ${ }^{\circ} 100$.

100 Hazard, H. W., The Numismatic History, 90, n. ${ }^{\circ} 3$.

101 Cf. Medina Gómez, A., Monedas hispano-musulmanas, 331. 
Voluntad divina - Camino de Dios - Guías - Meta (retorno a Dios) ${ }^{102}$.

La enseñanza es que Dios, en virtud de su voluntad soberana ( $a m r$ ), muestra un camino adecuado (hudà), por medio de Sus enviados (rusul), y gracias a su Discurso abajado (al-Qur'ān); la comunidad de los justos, esto es, de los prevenidos (al-muttaqūn), seguirá ese camino, ayudada, en el caso del almohadismo, por un maestro o imam, Ibn Tūmart, hasta alcanzar la meta de la salvación (al- 'äqiba). Ahora bien, es conocido que ese «maestrazgo» del Mahdī fue puesto en tela de juicio muy pronto entre los Mu'miníes. La cuestión planteada era si una comunidad histórica determinada puede realizar el camino hacia la salvación desprovista de un maestro humano que, como hizo Moisés con el pueblo de Israel, la siga guiando después de la irrupción divina; en otras palabras, si los musulmanes pueden responder a los designios divinos y regresar ${ }^{103}$ (al-ruýà $\left.{ }^{104}\right)$ a Él con la sola guía que Dios concedió por medio de su Discurso, el Corán. Esta segunda posibilidad es la que se diría que ilustran algunas monedas almohades, cuando comienzan a reflejar la crisis del discurso mesiánico.

\section{Respuesta al mesianismo}

En torno a los años 626 y 627/1228-30 podríamos fechar el comienzo del desmoronamiento del imperio almohade: Sevilla se ponía en manos de Ibn Hūd, y Túnez se independizaba bajo los Hafșíes ${ }^{105}$. Coincidiendo con estos hechos, el califa Abū 1-'Ulā Idrīs I al-Ma'mūn adoptó, en Marrakech, una serie de drásticas medidas, de

\footnotetext{
102 La expresión de este esquema de salvación a través de ideogramas relacionados con la marcha, el viaje y el retorno es insistente en el Corán, y, de este modo, el concepto de camino se constituye en una de las claves del Discurso divino. Se entiende, pues, que imágenes relacionadas con todo ello (la guía, el sendero, el encaminarse, etc.) se hayan vertido a otras lenguas por sus equivalentes. Cf., sin embargo, la opinión contraria -en cuanto a la traducción de estos y otros símbolos coránicos- de Zaborsky, A., "Etymology, etymological fallacy and the pitfalls of literal translation of some Arabic and Islamic terms", Arnzen, R, y Thielmann, J. (eds.), Orientalia Lovaniensia Analecta: Words, texts and concepts cruising the Mediterranean Sea, Lovaina-París-Dudley, 2004, 143-147.

${ }_{103}$ Acerca del islam como religión del regreso a Dios, si bien desde la perspectiva de la mística, Lings, M., ¿Qué es el sufismo?, Serra, E. (trad.), Palma de Mallorca, 2006, pas.

104 Corán, 86 Al-Tãriq, 8 y 11, y 96 Al-'Alaq, 8

105 Huici Miranda, A., Historia política, II, 475-476.
}

Al-Qanțara (AQ) XXVII 2, julio-diciembre 2006, pp. 477-527 ISSN 0211-3589 
orden teológico y canónico, que Ibn Jaldūn relata con precisión en su historia universal ${ }^{106}$. El nuevo califa, hijo del Abū Yūsuf Ya'qūb I al-Manșūr bi-Faḍl Allāh, prohibía, así, el ritual de llamada a la oración instaurado por Ibn Tūmart; negaba que éste fuera acreedor al título de al-Imām al-Mahdī al-Ma șūm (el Maestro y Mesías Impecable), y, en consecuencia, ordenaba que se omitiese cualquier alusión al pretendido Mahdī en las monedas ${ }^{107}$ y en el sermón del viernes. Otro historiador medieval, Ibn Abī Zar', proclive a los Meriníes, en tanto que Ibn Jaldūn lo era a los Hafșíes, proporciona algunos detalles complementarios al relato de las reformas de Idrīs I, entre ellos, uno pertinente a las monedas, al afirmar ${ }^{108}$ que «se redondearon los dírhams cuadrados que acuñaba el Mahdī».

La combinación de los datos anteriores llevó a los investigadores a preguntarse por la existencia de dírhams redondos, acuñados por Abū 1-'Ulā Idrīs I, con mención del nombre de éste y en cuya leyenda se omitiera al Mahdī ${ }^{109}$. Pero, como veremos enseguida, tales monedas, con todos esos rasgos, y a tenor de los datos arqueológicos de que disponemos, no existieron nunca. El hecho es que sí hay restos constatados de numerario en oro (que siempre se había acuñado en cospeles redondos) donde se menciona al susodicho califa almohade. A. Vives y Escudero ${ }^{110}$ registró la existencia de una dobla (o dinar de gran peso) entre cuyas inscripciones se incluía una donde sí se proclamaba: Al-Mahdĩ imām al-Umma (El Mesías, Maestro de la Comunidad). Y esa misma falta de monedas en oro a nombre de Idrīs I y sin la mención del Mahdī se sigue observando en obras contemporáneas sobre la amonedación mu'miní ${ }^{111}$. Sin embargo, sí que es conocida la

106 Kitāb al-'Ibar wa-dīwān al-mubtada' wa-l-jabar fī ayyām al- 'arab wa-l-barbar wa-man 'āsara-hum mi dawi l-sulțān al-akbar, Beirut, 1992, VI, 300.

107 Huici Miranda, A., Historia política, II, 477, parece interpretar mal el término árabe para "monedas", sikka, pues escribe que al-Ma'mūn mandó "suprimir el nombre del Mahdī en la ceca".

108 Al-Anīs al-mutrib, 1972 (251: "wa-dawwarū 1-darāhima 1-murakkanata llatī daraba-hā l-Mahdì”).

${ }^{109}$ La posibilidad de que la ruptura con el Mahdī se haya reflejado en la epigrafía ajena a las monedas se la ha planteado Martínez Núñez, M. A., "Ideología y epigrafía", 37-38, señalando que no es muy evidente el reflejo que haya podido dejar en inscripciones monumentales, salvo ejemplos marginales.

${ }_{110}$ Monedas de las dinastías, n. 2076.

111 Así, solamente se registra el tipo indicado en los trabajos, que citamos por orden cronológico, de Prieto y Vives, A., "La reforma numismática", 33; Hazard, H. W., The Numismatic History, 153; Ben Romdhane, K., Les monnaies almohades; Medina Gómez, 
innovación llevada a cabo, en las monedas de oro, por el hijo y sucesor de Idrīs I, 'Abd al-Wāḥid II al-Rašīd (r. 630-640/1232-1242), quien sustituyó, al menos durante una época, que debió de ser la primera de su reinado, cualquier fórmula de mención del Mahdī por otra que rezaba ${ }^{112}$ : al-Qur'ān ḥuŷyat Allāh (El Corán es fe de Dios), la cual parece reconocer la vía de salvación sin guías humanos, una vez cumplido el abajamiento del Discurso divino.

Así las cosas, dado que las fuentes hablan de monedas donde Idrīs I al-Ma'mūn omite el nombre del Mahdī, y de que su innovación en la forma no pudo afectar al oro; es explicable que los especialistas creyeran resolver el enigma atribuyendo las acuñaciones en plata en que se produjo el paso del cuadrado al círculo, no a Idrīs I, como afirmaba Ibn Abī Zar', sino a su hijo, 'Abd al-Wāḥid II al-Rašīd. Fue S. E. Lane-Poole ${ }^{113}$ quien, desde su destacada posición, difundió y avaló la idea de que existen unas monedas mu'miníes de plata, redondas y acuñadas por al-Rašĩd; aunque dependía de una información previa del orientalista danés J. G. C. Adler, quien, ya en el siglo XVIII, había registrado una de tales monedas al clasificar la colección Borgia de Roma 114:

Adler has also published [...] a circular dirhem of Er-Rasheed, tenth of the line; the circular form is explained by the orthodoxy of El-Ma-mūn [...]. ${ }^{115}$.

La autoridad de S. E. Lane-Poole motivó seguramente el que la atribución se repitiera en varios trabajos posteriores, algunos debidos

A., Monedas hispano-musulmanas, 420; en tanto que ninguna moneda de oro a nombre de Idrīs I aparece en los catálogos siguientes, que citamos también por orden cronológico: Canto García, A. e Ibrahim, T., Moneda andalusí en la Alhambra, Sevilla, 1997; Vega Martín, M. y Peña Martín, M., "El espacio numismático ibero-magrebí y los fondos del Museo Arqueológico y Etnológico de Granada", Al-Andalus-Magreb, 8-9, 1 (2000-01), 65-113; Canto García, A., Ibrāhīm, T. H. y Martín Escudero, F., Monedas andalusies: catálogo del Gabinete de Antigüedades, Madrid, 2000; Canto García, A. e Ibrāhīm, T. H., Moneda andalusí.

112 Prieto y Vives, A., "La reforma numismática", 29.

113 "On the coins of the Muwahhids in the British Museum", The Numismatic Chronicle, and Journal of the Numismatic Society, New Series 13 (1873), 147-170, 168.

${ }^{114}$ En una obra fuera de nuestro alcance: Adler, J. G. C., Collectio Nova Numorum Cuficorum seu Arabicorum Veterum Continens Numos Plerosque Ineditos e Museis Borgiano et Adleriano, Roma, 1782. autor.

15 Lane-Poole, S. E., "On the coins of the Muwahhids", la cursiva es del propio 
a numísmatas de primera fila, como F. Codera ${ }^{116}$, quien ofreció un resumen de la crisis epigráfica del «mahdismo» en las monedas almohades en los siguientes términos:

\footnotetext{
Hay algunos de estos dirhemes, aunque no con çeca española, en los cuales el nombre de Al-Mahdí ha sido reemplazado con la palabra al-Qur'ān [en caracteres árabes] leyéndose en ellos $\mathrm{Al}$-Qur'ān imāmu-nā [en caracteres árabes] $E l \mathrm{Ko}$ ran (es) nuestro Imam: estas monedas deberán suponerse acuñadas por el Califa almohade Idris Al-Mamun, que llegó á negar públicamente la autoridad y misión de Al-Mahdí, según nos dicen el autor del Kartás y otros: esto mismo vemos confirmado por alguna moneda en la que proclama Imam del pueblo al califa Al-Abbaçí.

Su hijo y sucesor Abu Moḥammad Abdo-l-Waḥid (II) Ar-Raxid llega á proclamarse Imam, ó hace que sus pueblos le proclamen, pues en sus monedas se lee: Ar-Raxid (es) nuestro Imam: los dos ó tres de sus sucesores de quienes conocemos moneda, vuelven á reconocer la misión divina de Al-Mahdí.
}

El avance de la numismática, disciplina de cuyos fundamentos fue F. Codera uno de los principales artífices ${ }^{117}$, nos permite en la actualidad señalar lo siguiente:

1) Muchos especialistas coinciden en que buena parte, al menos, de los dírhams cuadrados con la inscripción Al-Qur'ān imāmu-nā (El Corán es nuestro maestro) fueron acuñados por los Meriníes, como demuestra el peso de muchos de ellos, de unos 0,9 gramo, lo cual los sitúa fuera del sistema metrológico mu'miní, por más que el eslogan se avenga con la declaración que vimos en el oro del almohade 'Abd al-Wāhid II al-Rašīd, al-Qur'ān huŷŷat Allāh (El Corán es fe de Dios); acaso haya que considerar que los primeros pasos en este avance se dieron durante el último período mu'miní y que más tarde, con los Meriníes, se generalizó esta expresión del «antimahdismo»; el asunto, desde luego, requiere una investigación en profundidad.

2) Las monedas con las declaraciones al- 'Abbāsì imām al-umma (El abbasí es el maestro de la Comunidad), en oro, y al-'Abbāsī imāmu-nā (El abbasí es nuestro maestro) debieron de ser acuñadas por los Hūdíes ${ }^{118}$ y no por los Mu'miníes, quienes en sus monedas

116 Codera y Zaidín, F., Títulos y nombres propios en las monedas arábigo-españolas, Madrid, 1878, 35-36 (nota).

117 Viguera Molíns, M. J., "Al-Andalus prioritario: el positivismo de Francisco Codera", en Codera, Francisco, Decadencia y desaparición de los almorávides en España, Estella (Navarra), 2004, IX-CXXXVII, XCI y ss..

118 Por ejemplo, Rodríguez Lorente, J. J., Numismática de la Murcia Musulmana, Madrid, 1984, 119: . $^{\text {os }} 136$, para el oro y 137, para la plata.

Al-Qanțara (AQ) XXVII 2, julio-diciembre 2006, pp. 477-527 ISSN 0211-3589 
nunca dejaron de reclamar para sí la jefatura espiritual de la comunidad, como lo indica el que mantuvieran el título de amìr al-mu'minīn (emir de los creyentes). El dírham con el epígrafe mencionado ${ }^{119}$ presenta varios rasgos que justifican la confusión: su aspecto, su peso similar al de la unidad almohade (1,5 gramo) y la falta de nombres propios o años que es común a muchas de estas piezas y que está detrás de los problemas que plantean ${ }^{120}$.

3) Los dírhams redondos con la inscripción Al-Rašìd imāmu-nā (al-Rašīd es nuestro maestro) no fueron acuñados por los Mu'miníes, sino por los Alauíes de Marruecos, como veremos de inmediato.

Más adelante, después de F. Codera, la errónea atribución de los dírhams redondos indicados a 'Abd al-Wāhiid II al-Rašīd fue repetida en varias obras, debidas a estudiosos destacados: el corpus de H. W. Hazard ${ }^{121}$, los compendios de numismática islámica medieval, en su conjunto, de M. Mitchiner ${ }^{122}$, y el de numismática andalusí de A. Medina Gómez ${ }^{123}$ y el estudio, aludido más arriba, de $\mathrm{S}$. Fontenla Ballesta ${ }^{124}$. El primero de ellos, en efecto, registró - y el segundo lo confirmó-, como acuñadas por el mu'miní 'Abd al-Wāḥid II al-Rašìd, en las cecas de Rabat, Segilmesa, Fez y Marrakech, una serie de monedas que, de haber sido emitidas por éste, habrían representado una curiosa respuesta al problema del mesianismo. El modelo principal lo constituía una moneda de cospel irregularmente redondo, con un cuadrado inscrito en cada cara, de modo que se dejaban cuatro espacios para las leyendas, dos por lado (cuadrado inscrito y cuatro sectores). En los cuadrados centrales de éstos, y en una descuidada caligrafía, acorde con el aspecto tosco de la moneda, se leía una va-

119 Registrado, entre otros, por Bel, A., "Contribution à l'étude", 50; Hazard, H. W., The Numismatic History, n. ${ }^{\circ} 1118$; Prieto y Vives, A., "La reforma numismática", n. ${ }^{\circ}$ 65a, y Rodríguez Lorente, J. J. e Ibrāhīm, T.H., Numismática de Ceuta, n. ${ }^{\circ} 171$ y 172.

${ }_{120}$ Cf. Codera y Zaidín, F., Tratado de numismática arábigo-española, Madrid, 1874, 217: “[...] las monedas de los Almohades tienen menos importancia histórica que las anteriores, por la circunstancia de que en ellas nunca consta el año de acuñación y pocas las çeca, poniendo sólo el nombre del Príncipe ó Príncipes por quienes fueron acuñadas, y esto no siempre".

${ }_{121}$ The Numismatic History, 266-267 (n. ${ }^{\text {os }}$ 1078-1084).

122 Mitchiner, M., Oriental Coins and their Values: The Muslim World, Londres, 1977,102, n. ${ }^{\text {os }} 415-417$.

123 Monedas hispano-musulmanas, 435.

124 "Las primeras acuñaciones", 55.

Al-Qanțara (AQ) XXVII 2, julio-diciembre 2006, pp. 477-527 ISSN 0211-3589 
riante destacada del mensaje contenido en los dírhams mu'miníes usuales (Figura $3^{125}$ ):

FigURA 3.--Muzūna 'alawí a nombre de Mawlāy Rašīd

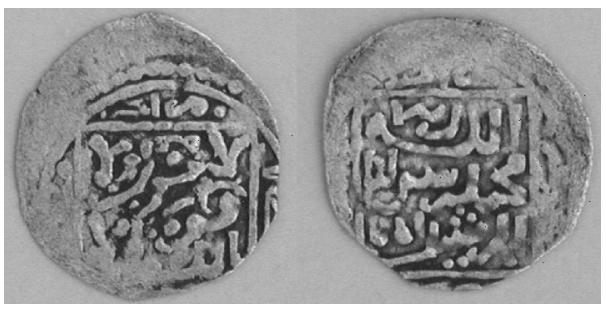

I.C

Là hawl wa-lā

quwwa illä

bi-[A]lläh

(Sólo hay potestad y fuerza por Dios)
II.C

Allāh rabbu-nā Muhammad rasūlu-nā al-Rašì imāmu-nā

(Dios, nuestro amo Muhammad, nuestro apóstol al-Rašīd, nuestro maestro)

En tanto que, en los cuatro sectores de ambos lados, se desarrollaba una misma inscripción con la data y la ceca, pero que, en razón del diseño de la moneda, resultaban difícilmente legibles, por quedar en parte fuera de los cospeles, y que, según las descripciones de H.W. Hazard y A. Medina Gómez, consistía en lo siguiente:

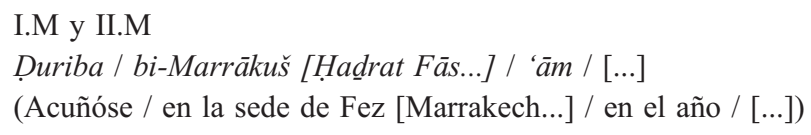

En suma, pues, la serie presentaba un conjunto de novedades respecto a la amonedación mu'miní anterior, pero también respecto a la meriní, hafsí y nazarí, de modo que, si realmente estuviéramos ante una acuñación de 'Abd al-Wāhid II, harían de ella un caso singular en la historia de la numismática, por las radicales reformas que habría suticular.

125 Moneda 'alawí, emitida por Mawlāy al-Rašīd; 0,820 g., 19,6 mm; colección par- 
puesto, tanto hacia atrás como hacia delante en la historia numismática. Comparemos, en primer lugar, las inscripciones de estos dírhams a nombre de al-Rašĩd con las del dírham almohade más conocido, que reprodujimos al principio del presente escrito. En las monedas que acabamos de describir, y que, según S. E. Stanley-Poole, F. Codera, H. W. Hazard, A. Medina Gómez y S. Fontenla Ballesta, siguiendo todos a J. G. C. Adler, fueron emitidas por 'Abd al-Wāḥid II al-Rašīd en observancia de la nueva orientación teológica de su padre, no solamente falta la mención del Mahdī, sino toda referencia, directa o indirecta, a los principios del movimiento almohade; así como cualquier alusión a la dinastía mu'miní, a pesar de la importancia que para la legitimación de un régimen sucesorio, y más aún el mu'miní almohade, tenían las genealogías ${ }^{126}$, de lo que dan fe sus monedas de oro ${ }^{127}$. Por otra parte, aún más chocante resulta el que 'Abd al-Wāhid II al-Rašīd se proclame él mismo imām (maestro), implicando que asume el papel del Mahdī. Esto habría significado no un cambio de orden teológico, en el esquema de salvación que vimos más arriba, sino simplemente la sustitución de un guía histórico (Ibn Tūmart) por otro (al-Rašīd).

En el aspecto técnico de la concepción y ejecución de la moneda, ya hemos aludido a ciertas imperfecciones impropias de las monedas almohades, y una evidente divergencia estilística, tanto en la caligrafía como en la ausencia de otros elementos, de tipo seguramente simbólico, tales como ornamentaciones vegetales o de otro tipo, que son propias de las monedas almohades. En segundo lugar, otro motivo, si bien limitado, para la extrañeza es el que todas la cecas registradas para estas monedas sean de ciudades actualmente marroquíes, y que falten otras, en el extremo noroeste de África, tales como Azemor y Ceuta que son habituales en el oro de 'Abd al-Wāhịid II, así como la de Málaga, donde tenemos constancia que siguieron acuñándose monedas almohades ${ }^{128}$. Con todo, éste es un inconveniente menor; habría cabido perfectamente que las acuñaciones del almohade 'Abd al-Wāhid II al-Rašīd se restringiesen a las cuatro cecas antes mencionadas (Rabat, Segilmesa, Rabat y Fez). Pero hay un motivo mayor de extrañeza ante

${ }^{126}$ Cf. Fierro, M., "Las genealogías de "Abd al-Mu'min, primer califa almohade", Al-Qanțara, XXIV, 1 (2003), 77-107.

${ }_{127}$ Cf. Ben Romdhane, K., Les monnaies almohades, y Vega Martín, M., Peña Martín, S. y Feria García, M. C., El mensaje de las monedas.

${ }_{128}$ Hazard, H. W., The Numismatic History, 266 y ss., y Medina Gómez, A., Monedas hispano-musulmanas, 422 y ss.

Al-Qanțara (AQ) XXVII 2, julio-diciembre 2006, pp. 477-527 ISSN 0211-3589 
la atribución almohade de estas acuñaciones, y es su peso. Según los datos que hemos manejado y los ejemplares a que hemos tenido acceso, la mayoría de estas monedas pesa 1,2 gramo, con ciertas variaciones a la baja. Este dato sitúa esta serie de monedas fuera del sistema metrológico almohade, donde la unidad de plata, el dírham, tenía un peso constante de en torno al 1,5 gramo, y también del patrón inmediatamente anterior, el almorávide, cuya unidad de plata tenía un peso de 0,9 gramo. Y mencionamos estos dos sistemas porque incluso los continuadores de los Mu'miníes en el espacio ibero-magrebí, esto es, los Meriníes y los Nazaríes acabaron por circunscribirse a alguno de los dos mencionados patrones para sus acuñaciones en plata.

Este cúmulo de rasgos y signos de diverso orden debería tal vez haber suscitado una mayor prudencia antes de formular en firme la atribución de estos dírhams redondos al califa almohade que sucedió a Idrīs I al-Ma'mūn. Principalmente, porque ya el punto de partida de dicha atribución, esto es, el seguimiento de la noticia facilitada por las fuentes históricas, en concreto por Ibn Abī Zar', mostraba una incongruencia. Pues éste habló de monedas redondas y sin mención del Mahdī, refiriéndose a Idrīs I y no a 'Abd al-Wāḥid II. La respuesta a todos estos interrogantes la proporcionó, sin apenas ser escuchado, J. D. Brethes, quien, a mediados del siglo XX, más de una década antes de la aparición del corpus de H. W. Hazard, publicó su colección particular de monedas acuñadas en Marruecos desde la Antigüedad hasta sus días. En su catálogo J. D. Brethes ${ }^{129}$ incluía la descripción, acompañada de imágenes, de esta serie de monedas, acuñadas en las cecas antes indicadas, con un peso de 1,2 gr., y con la leyenda señalada, pero atribuyéndolas no al almohade mu'miní 'Abd al-Wāhid al-Rašīid, sino a Mawlāy al-Rašīd (Moulay Rachid), el primer monarca de la dinastía alawí, que reinó ya en la occidental Edad Moderna, entre 1666 y 1672 (1075-1083 h.). Y, de hecho, J. D. Brethes sí que fechaba las monedas de esta serie, pues, como se aprecia, a veces con dificultad, en los ejemplares a que hemos tenido acceso directo o fotográfico, los dírhams a nombre de al-Rašīd muestran una datación (lo que no hacían jamás los Mu'miníes ${ }^{130}$ ), y no escribiendo los nom-

129 Contribution à l'histoire de Maroc par les recherches numismatiques, Casablanca, 1939, 226, n. ${ }^{\text {os }} 1629-1632$.

${ }_{130}$ Cf. Vega Martín, M., Peña Martín, S. y Feria García, M. C., El mensaje de las monedas.

Al-Qanțara (AQ) XXVII 2, julio-diciembre 2006, pp. 477-527 ISSN 0211-3589 
bres de los números, sino con su notación en cifras arábigas; de modo que, en los ejemplares acuñados en Fez, por ejemplo, se lee la frase 'ām 1079, o sea, «[acuñado] en el año 1079 [h./1668-9 d. C.]». Así pues, las diferencias sustanciales entre las monedas de plata almohades y éstas erróneamente atribuidas a 'Abd al-Wāhid II se explican no por cambios teológicos, sino por paso del tiempo. Entre los reinados de uno y otro monarcas llamados al-Rašĩd mediaron, en efecto, cuatro siglos; aunque es, con todo, evidente que algunos elementos del ideario legitimador político-religioso permanecieron ${ }^{131}$. Volviendo a la historiografía numismática, la atribución de estas monedas al 'alawí (y no almohade) al-Rašīd fue confirmada, después de J. D. Brethes, por D. Eustache, quien en su corpus de moneda 'alawí 132 describía minuciosamente las únicas monedas de plata (llamadas muzūna < mawzūna 'pesada') que acuñó Mawlāy al-Rašîd ibn al-Ḥarîf, añadiendo lo siguiente ${ }^{133}$ :

Ces monnaies on été répertoriées par erreur dans HAZARD (nos 1078-1084, pp. 266-7); cet auteur les a attribuées à Abū Muhammad 'Abd al-Wāḥid I [er-Rašīd] ibn Idrīs I [el-Ma'mūn], souverain almohade (630-640 H./1234), «struck before restoration of al-Mahdī's name, A. H. 630-631 / A. D. 1232-1234».

La misma atribución, alawí, de las monedas redondas de al-Rašĩd la encontramos en los dos catálogos de monedas islámicas más difundidos en la actualidad, el de S. Album ${ }^{134}$ y el de C. L. Krause y C. Mischler ${ }^{135}$, el segundo de ellos, dedicado a las piezas acuñadas del período que en Occidente se considera moderno y contemporáneo. Este dato nos permite extraer una conclusión metodológica en cuanto a la investigación sobre el islam. Y es que a la perpetuación del error de J. G. C. Adler y S. Lane-Poole ha debido de contribuir el que se apliquen a lo islámico divisiones históricas occidentales que se muestran inadecuadas para muchos objetos, como éste de las monedas islámicas. Se diría, en efecto, que los interesados en monedas emitidas antes del siglo XVI d.C. han prestado poca atención a las acuñaciones islámicas de siglos

131 Cf., para la pervivencia del mahdismo siglos más tarde de los almohades, cf. García-Arenal, M., "Pouvoir sacré et mahdisme: Aḥmad al-Mansūr al-Dhahabī", Al-Qanțara, XVII, 2 (1996), 453-471.

132 Eustache, D., Corpus des monnaies alaouites, Rabat, 1984, II, 663, y lám. I.

133 Ibídem, II, 663.

134 A Checklist of Islamic Coins, Santa Rosa (California), 1998², 42.

135 Standard Catalogue of World Coins, 1601-1700, s.l., 2003³, 1076. 
posteriores, siendo así que, en muchos aspectos, la historia numismática del Magreb no permite establecer esa separación ${ }^{136}$.

\section{La plata de Idrīs I}

Una vez rechazada la atribución de esas monedas al mu'miní al-Rašīid, sigue en pie la cuestión de cuáles son las correspondientes a las noticias de Ibn Jaldūn y, sobre todo, de Ibn Abī Zar', es decir, el dírham redondo almohade y sin la mención del Mahdī. Precisamente por el detalle de que estamos buscando unas monedas redondas, hemos de descartar la solución sugerida por A. Bel ${ }^{137}$, a quien siguió $\mathrm{F}$. Mateu ${ }^{138}$, los cuales atribuyen a Idrīs I al-Ma'mūn los dírhams cuadrados con el contenido epigráfico que suele atribuirse a las monedas de plata meriníes, es decir, con la sustitución de la fórmula Al-Mahdī imāmu-nā (El Mahdī es nuestro maestro) por Al-Qur'ān imāmu-nā (El Corán es nuestro maestro) ${ }^{139}$, similar, pero no idéntica, a la que vimos antes en las monedas de oro de 'Abd al-Wāhiid II al-Rašīd, y que A. Bel denominó «dirhems almohades impliquant la répudiation du Mahdi» ${ }^{140}$. Efectivamente, tal vez se trate de un precedente de los dírhams meriníes más usuales, que suelen presentar un peso de 0,9 gramo, como dijimos más arriba. El hecho de que también se hayan descrito dírhams cuadrados con la leyenda de Al-Qur'ān imāmu-nā, cercanos en su peso al modelo mu'miní ${ }^{141}$, complica un poco más esta confusa situación, ya que, como decimos, el patrón meriní más usual coincide con la unidad de plata almorávide, el quirate, con un peso de 0,9 gramo. Así pues, la propuesta de A. Bel no nos saca del atolladero en que estamos, pero sí que es indicio de las variadas mo-

${ }^{136}$ La necesidad de no detenernos en las postrimerías del siglo XV d. C. al estudiar la historia del Islam la han defendido, desde ámbitos ajenos a las monedas, García-Arenal, M., Rodríguez Mediano, F. y El Hour, R., Cartas marruecas: documentos de Marruecos en archivos españoles (siglos XVI-XVII), Madrid, 2002, 9.

137 "Contribution à l'étude", 43 y ss.

138 Mateu y Llopis, F., "Hallazgos numismáticos musulmanes, II", Al-Andalus, 15 (1950), 217-226, 220-222.

139 Acerca de la especial consideración del Corán entre los Meriníes, cf. Manzano Rodríguez, M. Á., "El sultán y el Corán: notas sobre algunas referencias en la historiografía magrebí bajomedieval", Estudios coránicos en honor del Profesor Julio Cortés, Hernando de Larramendi, M. y Peña Martín, S., en preparación.

140 "Contribution à l'étude", 43.

141 Medina Gómez, A., Monedas hispano-musulmanas, 438. 
nedas que hemos de considerar posteriores a la crisis del modelo almohade, por la omisión de leyendas mahdistas. Por otro lado, nada de esto ayuda a resolver los problemas que sigue planteando el sistema monetario meriní ${ }^{142}$, lo que está lejos de nuestro objetivo aquí.

Pero suele ocurrir, en este ámbito de las monedas almohades y postalmohades, que un trabajo fundamental, el de A. Prieto, a pesar del tiempo transcurrido desde su publicación (en 1919) y de sus múltiples aciertos, sigue sin haber alcanzado la repercusión que hubiese sido de esperar para el avance de nuestros conocimientos. Lo cierto es que A. Prieto ya señaló ${ }^{143}$ la existencia de

una moneda almohade de forma redonda; tiene las leyendas iguales a las del semidirhem, encerradas en un cuadrado como en las monedas de oro, pero sin leyenda en los segmentos; su peso es el del dirhem. Creemos que esta moneda fue acuñada durante la reforma de Idris I y que a ella se refieren los historiadores al decir que se suprimió el nombre de Mahdī y volvió a las monedas su forma redonda.

El argumento del peso es, a todas luces, decisivo. Aunque las inscripciones de esta moneda coincidan con las del medio dírham, como cierto ejemplar acuñado en Murcia y procedente del hallazgo de Priego (Figura $4{ }^{144}$ ), estamos, en realidad, ante un dírham, muy probablemente ante el de Idrīs I al-Ma'mūn, por más que el único nombre que aparezca en la moneda sea el del 'Abd al-Mu'min ibn 'Alī, el funda-

FigurA 4.--Medio dírham de 'Abd al-Mu'min

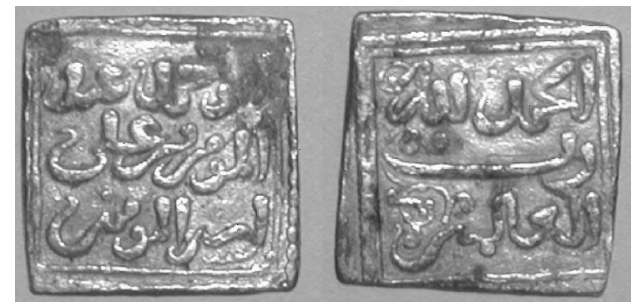

142 Cf. al-Salāmī, R., "Qirā'a fī 1-nuqūd al-marīniyya”, Maŷallat Kulliyyat al-Ādāb wa-l- 'Ulūm al-Insāniyya (Ŷàmi'at Muhammad al-Jāmis, Rabat), 23 (1999), 179-227, 214 y ss.

143 "La reforma numismática", 32. Hay que reconocer que sí se hizo eco de ello Medina Gómez, A., Monedas hispano-musulmanas, 433.

144 Medio dírham almohade acuñado en Murcia; Museo Arqueológico y Etnológico de Córdoba.

Al-Qanțara (AQ) XXVII 2, julio-diciembre 2006, pp. 477-527 ISSN 0211-3589 
dor de la dinastía, en un lado, y la frase coránica que sirvió de lema a ésta, con arreglo al siguiente esquema (Figura $5{ }^{145}$ ):

FIGURA 5.-Dírham acaso acuñado por Abū 'Ulā Idrīs I al-Ma'mūn

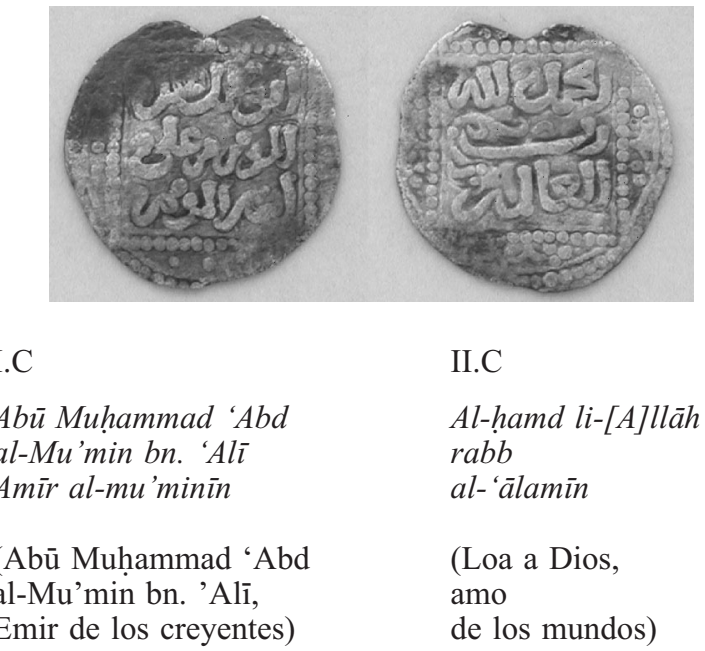

$\mathrm{Y}$ hemos de desechar como contrargumento el que se mencione a un califa ya muerto, pues se trata del epónimo de la dinastía, y, por estos tiempos, también los Hafșíes de Túnez emprendían una amonedación que trataba de emular la de 'Abd al-Mu'min en muchos de sus detalles, incluida la mención del nombre de éste y la frase al-Hamd li-[A]llāh rabb al- 'älamin; pero, eso sí, proclamando, en respuesta a la desafección mahdista de Idrīs, nada menos que Al-Mahdī jalīfat Allāh (el Mahdī es el Vicario de Dios) ${ }^{146}$. Si estamos en lo cierto, si las monedas almohades y mu'miníes donde no se menciona Mahdi y se vuelve a la forma circular, son estos dírhams de 1,5 gramos con la misma leyenda que el medio dírham de 'Abd al-Mu'min; entonces podríamos sostener también una explicación para las monedas redondeadas con las inscripciones del cuarto de dírham, pero con el peso

145 Dírham acaso acuñado por Idrīs I al-Ma'mūn; 1,39 g., 18,7 mm. Ø; colección particular.

146 Prieto y Vives, A., "La reforma numismática", 113; Hazard, H. W., The Numismatic History, n. ${ }^{\circ} 542$.

Al-Qanțara (AQ) XXVII 2, julio-diciembre 2006, pp. 477-527 ISSN 0211-3589 
del medio, de las que hablamos antes, cuando rechazamos su atribución a los Nazaríes. De manera que el sistema de Abū 1-'Ulā Idrīs I quedaría constituido por los dírhams con la leyenda 'Abd al-Mu'min ibn 'Alī amīr al-mu'minin / Al-hamd li-l-[A]llāh rabb l-'älamin, y su fracción, el medio dírham con la leyenda Hudà [A]llāh huwa l-hudà I Al-'āqiba li-l-taqwà. Ambas monedas son redondas, en una de ellas se recuerda la autoridad dinástica como principio legitimador, y en ninguna de ellas se menciona al Mahdī, pero sí se reconoce la Guía de Dios como medio de salvación (Figura $6^{147}$ ).

FiguRA 6.-Medio dírham acaso acuñado por Abū 1-'Ulā Idrīs I al-Ma'mūn

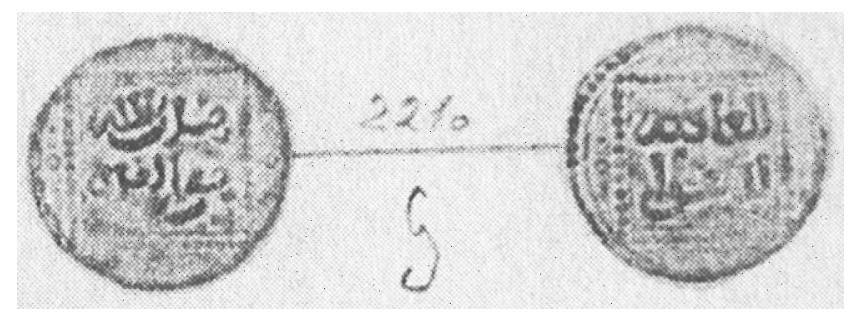

Antes de seguir adelante, hagamos notar que el contenido de las inscripciones del medio dírham de 'Abd al-Mu'min y tal vez el dírham de Idrīs al-Ma'mūn parecen aludir a la contraposición entre este mundo y el otro; ya que, si en una de sus caras se menciona al fundador de la dinastía, la fórmula de la otra: al-Hamd li-l-[A]llāh rabb l-'álamin (Alabanza a Dios, Amo de los mundos), constituye una especie de «alfa y omega», si se nos permite la analogía cristiana, pues, como ya se advierte al comienzo de uno de los libros clásicos del islam medieval, el tratado de gramática de Sïbawayhi (m. 177/793), ésa no es sólo la primera frase efectiva del Corán, sino la última oración de los fieles en el paraíso ${ }^{148}$.

\footnotetext{
147 Reproducción del que pudo ser fracción del dírham de Idrīs I, tomada de Vives y Escudero, A.; Monedas de las dinastías arábigo-españolas: láminas, Madrid, 1998, 227 (lám. CCXXV).

${ }^{148}$ Kitāb, ed. 'A. S. M. Hārūn, Beirut, s.d., I, 5.
} 


\section{Una inscripción inadvertida}

Incluso aunque aceptemos como definitiva esta atribución de las monedas «redondeadas», que es sólo conjetural, tampoco podemos darnos por satisfechos en nuestra busca. Como es bien sabido, el discurso mahdista comenzó a deteriorarse antes de que Idrīs I llegara al poder. D. Urvoy ${ }^{149}$ ha mostrado cómo Averroes estuvo comprometido en la labor de al-Manșūr consistente en una fundamentación de lo almohade ajena al mahdismo. Y bien, ¿se tradujo este movimiento en las inscripciones numismáticas? Antes de lanzar una hipótesis al respecto, recordemos que el célebre estandarte que portaban las tropas musulmanas en la batalla de Alarcos ${ }^{150}$, llevaba una leyenda triple, en la que ni se mencionaba al Mahdī ni se mantenía, por tanto, la teología «triangular» y descendente (Allāh-Muhammad-Mahdī) propia de varias corrientes islámicas carismáticas. En lugar de ello, el estandarte proclamaba ${ }^{151}$ la profesión de fe en el Dios único y la misión de Muhammad, añadiendo una frase lo suficientemente ambigua como para servir a distintas orientaciones teológicas, pero muy adecuada para la teología «unicista» de los almohades, el célebre Là gālib illā [A]llāh (Soberano sólo es Dios ${ }^{152}$ ):

Là ilāh illā Allāh

Muhammad rasūl Allāh

Là gālib illā [A]llāh

(No hay sino un Dios

Muhammad es el apóstol de Dios

Soberano sólo es Dios)

149 Urvoy, D., Averroes, especialmente 104 y 153.

150 Sobre esta batalla, Buresi, P., "L'apogée almohade: la bataille d'Alarcos et son contexte historique", Averroès et l'averrö̈sme: Un itinéraire historique du Haut Atlas à Paris et à Padoue, ed. Bazzana, A., Bériou, N. y Guichard, P., Lyon, 2005, 99-113.

${ }^{151} \mathrm{Ibn} \mathrm{Abī} \mathrm{Zar}$, al-Anīs al-mutrib fì raw ḍ al-qirțās, 228; este texto era bien conocido de los investigadores del siglo XIX, como lo demuestran Oliver Hurtado, J. y M., Granada y sus monumentos árabes, Málaga, 1875, 63. Acerca del que acabó siendo lema nazarí, además, Peña Martín, S. y Vega Martín, M. "Epigrafía y traducción: el lema nazarí en su marco numismático", García Peinado, M. Á. y Ortega Arjonilla, E. (eds.), Panorama actual de la investigación en traducción e interpretación, Granada, 2003, II, 35-49, y "La clave de la guerra en el diálogo islam-cristiandad: epigrafía, imaginería y traducción", en Desde el sur: el discurso sobre Europa (actas del X Simposio Internacional de la Asociación Andaluza de Semiótica, Granada, 11-13 de diciembre de 2003), en prensa.

152 Sobre esta versión, Peña Martín, S. y Vega Martín, M., "Epigrafía y traducción" y "La clave de la guerra".

Al-Qanțara (AQ) XXVII 2, julio-diciembre 2006, pp. 477-527 ISSN 0211-3589 
De manera que cierta ruptura con el mahdismo fue muy temprana entre los Mu'miníes, por lo que cabría esperar que hubiese tenido repercusiones en las monedas. En este marco es donde deseamos situar la existencia de otra serie de monedas, también enigmática, de nuevo por la indeterminación que caracteriza a las monedas almohades y postalmohades. Se trata de ciertos dírhams mu'miníes, semejantes a los abundantemente conservados y descritos por doquier, pero que presentan un rasgo que hasta ahora no se ha señalado, que sepamos. Ello es que incluyen las siguientes inscripciones, donde lo que varía, respecto del modelo usual, es la tercera del reverso, como se comprueba comparando un dírham de los usuales con uno de estos otros (Figura $7{ }^{153}$ ):

FIGURA 7.-Dírhams almohades con mención del al-Mahdī y al-hudà

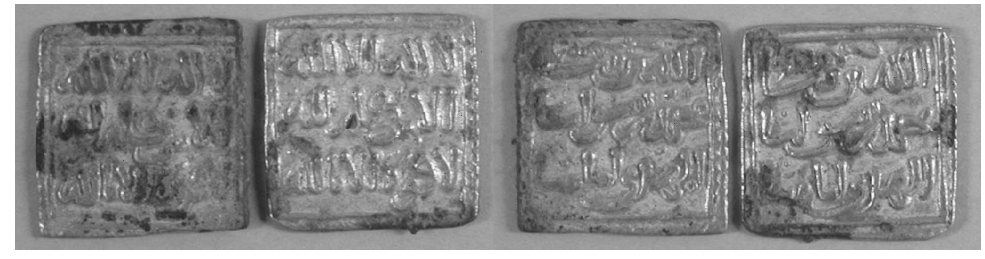

I.C

\section{Là ilāh illā Allāh}

Al-amr kullu-h li-[A]llāh

Là quwwa illā bi-[A]llāh

(No hay divinidad sino Dios

La disposición toda es de Dios

Sólo hay fuerza por Dios)
II.C

Allāh rabbu-nā

Muhammad rasūlu-nā

al-hudà imāmu-nā

(Dios, nuestro amo

Muhammad

La Guía [de Dios], nuestro maestro)

Se trata, pues, del dírham almohade cuadrado, pero con una variación epigráfica tan leve que ha pasado, al parecer, inadvertida a los estudiosos. En efecto, en grafía árabe la notación de las palabras al-Mahdī (el Mahdī, el Guiado, el mesías) y al-hudà (la guía) sólo se distinguen por un pequeño trazo circular, el de la letra mimm medial. Y es un hecho fácilmente constatable que existen dírhams almohades en

\footnotetext{
153 Anversos y reversos de sendos dírhams almohades del hallazgo de Priego de Córdoba; en el reverso del situado a la derecha se lee Al-hudà imāmu-nā; Museo Arqueológico y Etnológico de Córdoba.
}

Al-Qanțara (AQ) XXVII 2, julio-diciembre 2006, pp. 477-527 ISSN 0211-3589 
los que, en lugar de leerse Al-Mahdī imāmu-nāa, se lee Al-Hudà imāmu-nā. Por supuesto, podría pensarse, bien en un desperfecto debido a la mala conservación de algunos ejemplares, o bien de algún lapsus del grabador, pero esta posibilidad parece que debemos rechazarla por la presencia de la inscripción Al-Hudà imāmu-nā en monedas de excelente ejecución y aceptable conservación, como algunas del hallazgo de Priego de Córdoba (Figura 7). También podría pensarse que fueran millareses, la imitación cristiana de los dírhams almohades ${ }^{154}$; pero esto tampoco parece poder mantenerse, ya que, aun a la espera de un necesario estudio sobre la epigrafía del millarés, las monedas de las que hablamos muestran no sólo una caligrafía muy cuidada, sino diferente de la que suele observarse en las imitaciones cristianas. Por otro lado, la invocación de la Guía de Dios, en lugar de una figura mesiánica humana, está en consonancia con lo esencial del mensaje escatológico islámico y con la crisis del mahdismo entre los Mu'miníes. Dentro de la bruma de ambigüedad propia de las monedas almohades y postalmohades, estos dírhams, que incluso podrían haber sido acuñados por Abū Yūsuf Ya'qūb I al-Manșūr, por lo que hemos dicho más arriba, aportan un dato más que ha de ser tenido en cuenta, de cara a la difícil reconstrucción de los sistemas numismáticos que estuvieron vigentes en el Ándalus y el Magreb a partir de la decadencia almohade, y que corresponden al renovado discurso islámico en que el lugar concedido a una figura mesiánica se asigna a la propia Guía de Dios, manifestada en el Corán. Y, desde luego, tendríamos aquí un claro precedente a la explícita declaración meriní: al-Qur'ān imāmu-nā (El Corán es nuestro maestro). En realidad, la idea de que el Corán es el imām o Guía de los musulmanes, estaba asentada ya en el ámbito islámico desde hacía varios siglos ${ }^{155}$.

\footnotetext{
154 Sobre los millareses, entre otros, los trabajos, que citamos por orden cronológico, de Boneschi, Paulo, "Problemas de numismatica e metrologia maǵribīnas", Rivista degli Studi Orientali, 10 (1923-25), 377-405, 388 y ss.; Mateu y Llopis, F., "El castillo y la llanura", Boletín de la Sociedad Castellonense de Cultura, XXVIII, 1 (1952), 27-43, 34 y ss.; Riera Melis, A., "Monedas y mercados en la Edad Media: el Mediterráneo noroccidental (c. 1190-1350)", en Moneda y monedas en la Europa medieval (siglos XII-XV), Pamplona, 2000, 193-256, y Pellicer i Bru, J., "Sobre los millareses y su transición al croat en el señorío de Aragón (siglo XIII)", Gaceta Numismática, 158-159 (2005), 43-80.

${ }^{155}$ Cf. Ibn Fāris Ibn Zakariyyā, Abū l-Husayn Ahmad, Maquayiżs al-luga, ed. 'A. S. Hārūn, Beirut, 1991, I, 28: “wa-1-Qur'ānu imāmu 1-muslimīn”.
}

Al-Qanțara (AQ) XXVII 2, julio-diciembre 2006, pp. 477-527 ISSN 0211-3589 


\section{Un «aire de familia»}

No es solamente el empleo del cuadrado o algunos rasgos estéticos lo que confiere a las monedas de la reforma almohade un cierto aire de familia. Son otras las características, más relacionadas con el discurso epigráfico, lo que nos fuerza a considerar como un mismo objeto de estudio a las monedas emitidas por Mu'miníes, Hafșíes, Meriníes, Nazaríes y Ziyaníes, como mínimo. El uso de las monedas como soportes para el desarrollo de una teología que fue evolucionando forma asimismo parte de esa comunidad de rasgos. Fue, que sepamos, S. Lane-Poole ${ }^{156}$ el primero que hizo notar la posible confusión entre las monedas almohades (cuadradas o con un cuadrado inscrito en un círculo) acuñadas por los Mu'miníes y las emitidas por las dinastías posteriores, singularmente las de los Ḥafșíes, quienes mantuvieron vivo el discurso almohade en torno a la figura central del «mesías» Ibn Tūmart. Tal vez por ese motivo los Hafṣíes acuñaron monedas que no sólo estaban inspiradas por los primeros modelos numismáticos mu'miníes ${ }^{157}$, sino que, en algunos casos, las imitaban hasta tal punto que puede resultar muy difícil distinguirlas de las mu'miníes ${ }^{158}$. Se da así la circunstancia de que uno de los emblemas más destacados de los sucesores de 'Abd al-Mu'min ibn 'Alī, el dírham almohade genuino, puede ser confundido tanto con las imitaciones cristianas de la época (millareses) como con algunas series de dírhams emitidos por los Hafșíes de Túnez. J. Farrugia de Candia ${ }^{159}$ ha descrito vívidamente la situación al referirse a la convivencia, en la ciudad de Túnez durante los siglos XIII y XIV d. C., es decir, en el tiempo y lugar de Ibn Jaldūn, de millareses de imitación cristiana y dírhams hafșíes. El mencionado investigador ofreció en su momento una catalogación de los ejemplares de estos últimos que se encontraban en el Museo del Bardo de Túnez, señalando que, con idénticas leyendas que la unidad en plata de los Mu'miníes, los Hafṣíes emitie-

\footnotetext{
156 Lane-Poole, S., Catalogue of Oriental Coins in the British Museum, Londres, 1875-1891, V, 51-57, apud Farrugia de Candia, J., "Monnaies hafsites du Musée du Bardo", Revue Tunisienne, N. S. 138, 231-288, 231.

157 Cf., acerca de este problema, Medina Gómez, A., Monedas hispano-musulmanas, 405 , y sus referencias, además de las que facilitamos en el presente texto. 455-456

158 Sobre esta cuestión, Fontenla Ballesta, S., "Numismática y propaganda",

159 Farrugia de Candia, J., "Monnaies hafsites", 232 y ss.
}

Al-Qanțara (AQ) XXVII 2, julio-diciembre 2006, pp. 477-527 ISSN 0211-3589 
ron otras monedas cuyas diferencias con las anteriores eran muy escasas ${ }^{160}$ :

Les dirhams almohades sont très réguliers de forme et de bon aloi. Parfois leurs légendes sont dans un coufique simple et archaïque; quand les caractères sont magrébins, l'écriture est cursive et très stylisée, le décor floral très élégant. Les dirhems des Hafsides, très irréguliers de poids et de forme, ont un titre inférieur et très variable; l'écriture, un peu différente, et à caractères plus gras.

Así las cosas, la diferenciación, necesaria desde la perspectiva histórica y arqueológica entre los dírhams mu'miníes y hafșíes, ha de basarse en el rasgo del peso de las monedas. Y, en efecto, los ejemplares catalogados por J. Farrugia de Candia, presentan valores muy inferiores al 1,5 gramo de gran parte de los dírhams almohades ${ }^{161}$, concretamente en torno a los 1,25 gramo o algo por encima de esto ${ }^{162}$. Los mismos datos los confirmó y los amplió más tarde Ḥ. H. 'Abd al-Wahhāb ${ }^{163}$, quien catalogó dírhams, con las mismas inscripciones que el mu'miní, acuñados en distintas cecas, o sin indicación al respecto, y con distintas variedades de caligrafía, señalando que el peso de los ejemplares considerados estaba en torno al gramo o hasta dos décimas más; es decir, entre tres y cinco por debajo del peso que suelen presentar los ejemplares no agredidos del dírham mu'miní y de su imitación cristiana. Llama, por este motivo, poderosamente la atención la copiosa colección de monedas cuadradas en plata conservadas en la Real Academia de la Historia de Madrid. Son más de ochocientos ejemplares de dírhams catalogados como almohades, en el sentido de almohades mu'miníes 164 por los autores del catálogo, pero que, a la luz de los datos de J. Farrugia y Candia y H. H. ' 'Abd al-Wahhāb, acaso habría que considerar hafsíes, pues el peso de la mayoría de ellos es de entre 1,1 y 1,2 gr. y, como se aprecia claramente en las imágenes ofrecidas, están en gran parte acuñados en cospeles irregulares.

Este último hecho, junto a los que hemos ido considerando en las páginas precedentes, es prueba manifiesta de la indeterminación en que ha de moverse el estudioso de las monedas acuñadas en virtud de

160 Ibídem, 233.

161 Cf. Vega Martín, M. y Peña Martín, S., "El espacio numismático”, 97 y ss.

162 Farrugia de Candia, J., "Monnaies hafsites", 287-8.

163 'Abd al-Wahhāb, H. H.., al-Nuqūd al-'arabiyya fì Tūnis, Túnez, 1968, 147-149. 238-293.

164 Canto García, A., Ibrāhīm, T. H y Martín Escudero, F., Monedas andalusies, 
las reformas numismáticas impulsadas por los Mu'miníes. Y justifica, por un lado, la prudencia que ya mostró A. Prieto en su excelente corpus ${ }^{165}$, al no atreverse a precisar con seguridad a qué dinastía es necesario atribuir algunas de las series. Ciertamente, es arriesgado atribuir algunas de estas piezas del cuadrado y con ese «aire de familia» del que hablamos a una u otra de las dinastías postalmohades, para empezar, porque éstas mantuvieron lazos de reconocimiento mutuo que se pudo plasmar en las monedas. Así, H.W. Hazard, en su corpus de monedas islámicas norteafricanas, al clasificar el oro hafșí, se veía obligado a distinguir entre monedas «with Muwaḥid name»" ${ }^{166}$, refiriéndose a las doblas que llevan el nombre del 'Äbd al-Mu'min ibn 'Alī grabado, frente a otras, entre muchas más, donde advertía «Marīnid influence». En tanto que, dentro de la serie meriní, señalaba monedas «anonymous with Nașrid inscription», refiriéndose al lema Là gãalib illā Allāh (Soberano sólo es Dios), que, como sabemos es mu'miní por más que los Nazaríes lo emplearan con profusión; después de haber hablado de una gran variedad de piezas que atribuía a Abū Bakr ibn 'Abd al-Haqq I (r. 642-656/1244-1258) y su sucesor, y que caracterizaba por su «Hafșid style», a causa del reconocimiento de la autoridad hafsí. De una de estas últimas, cierta fracción de dinar que el numísmata norteamericano clasificó bajo esta última rúbrica, tenemos constancia de un hallazgo en el llamado Corral del Carbón, la que fuera alhóndiga nazarí de Granada ${ }^{167}$. Pues bien, ya se trate de una acuñación meriní ${ }^{168}$, o de una moneda hạașí, como también se ha sostenido ${ }^{169}$, lo cierto es que tenemos constancia de su circulación por el territorio andalusí y seguramente también por el del actual Marruecos. Pero la moneda, como otras de series similares, nos interesa por otros motivos. Recordemos su leyenda (Figura $8{ }^{170}$ ):

\footnotetext{
165 Prieto y Vives, A., "La reforma numismática".

166 The Numismatic History, respectivamente, 159, 173, 206, 192 y n. ${ }^{\circ} 706$.

167 Cf. Torres Balbás, L., "Las alhóndigas hispano-musulmanas y el Corral del Carbón de Granada", Al-Andalus, XI (1946), 447-480.

168 Cf. Vega Martín, M. y Peña Martín, S., "Allāh ḥasbī, lema coránico (IX: 129) en una moneda meriní hallada en Granada", Miscelánea de Estudios Árabes y Hebraicos (Sección Árabe-Islam), 51 (2002), 327-338, donde los autores podrían haberse mostrado más prudentes en la atribución.

${ }_{169}$ Farrugia de Candia, J., "Monnaies hafsites", n. ${ }^{\circ} 70$.

170 Fracción de dinar, acaso meriní; 0,5 g., 13,55 mm. Ø; Museo Arqueológico y Etnológico de Granada.
}

Al-Qanțara (AQ) XXVII 2, julio-diciembre 2006, pp. 477-527 ISSN 0211-3589 
FIgURA 8.-Fracción de dinar, acaso meriní

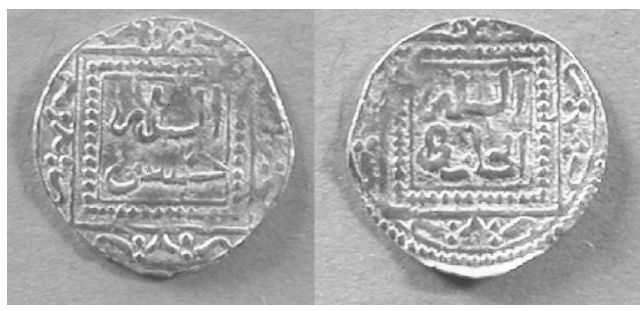

I.C

II.C

Allāh
hasbì

Allāh

al-Häfiz

(Dios

(Dios,

me basta)

el Guardián)

Y es que, a pesar de la brevedad del texto que ofrece, la doble inscripción es indicio de dos rasgos sobresalientes en el discurso numismático religioso postalmohade: 1) la vuelta, en el anverso, a expresiones individuales de la religiosidad, que habían sido frecuentes en las monedas almorávides, y 2) el recurso, en el reverso, a la teología afirmativa, esto es, a la que, como ya hemos indicado, caracteriza a Dios no en virtud de lo que se no puede decir de Él, sino por predicaciones de sus cualidades. Si bien es cierto que el propio Corán recoge y subraya muchas de tales predicaciones de Dios, también lo es que la teología impulsada por Ibn Tūmart tendía a las predicaciones negativas propias de la teología apofática, derivada del mu'tazilismo ${ }^{171}$. Ilustrativo resulta el texto de su famosa Profesión de fe ${ }^{172}$ en la que dominan tales negaciones:

Alabado sea Aquel de Quien indicios y signos confiesan que el tiempo no Lo alcanza, la percepción no Lo abarca, la necesidad no Lo toca, el daño no Le sobreviene. Aquel Que es conocedor de todo lo cognoscible, Aquel que dispone en todo lo existente, Aquel Que no actúa con instrumentos, Aquel para Quien no son confusos los sonidos, Aquel a Quien no se le oculta lo oculto, Aquel Que no se parece a los seres creados, Aquel para Quien no es finito lo realizable, Aquel para

171 Al respecto, Pareja, F. M., La religiosidad musulmana, Madrid, 1975, 125.

$172 A^{\prime} a z z$ mà yutlab, 226; una primera versión la ofrecimos ya en otro lugar (Vega Martín, M., Peña Martín, S. y Feria García, M. C., El mensaje de las monedas, 311). 
Quien no está limitado lo cognoscible: excede de todo condicionamiento, y es Dios de quien en la tierra está.

La tendencia se invierte en las versiones evolucionadas del discurso almohade, después de pasada su crisis, como se comprueba o en las inscripciones de la Alhambra de Granada ${ }^{173} \mathrm{o}$ en las monedas meriníes ${ }^{174}$, como la que va a ocuparnos a continuación.

\section{Teología afirmativa}

Se trata de una dobla inédita, que sepamos, y que, a pesar de no incluir mención de autoridad emisora, debemos probablemente atribuir a Abū Yahyà Abū Bakr ibn 'Abd al-Haqq (r. 642-656/1244-1258), el primer monarca meriní de quien suelen registrarse acuñaciones, algunas de las cuales presentan claras similitudes con ésta ${ }^{175}$. Sus epígrafes creemos que arrojan luz sobre el discurso postalmohade. Helos aquí, comenzando por los cuatro segmentos del margen (IM) del lado donde aparece la frase de encabezamiento Bi-sm Allāh al-Raḥmān al-Rahim (En el nombre de Dios, Clemente, Misericordioso), y que, por eso mismo, consideramos el anverso (Figura $9{ }^{176}$ ):

\section{Figura 9.-Dobla meriní con la inscripción} Là ilāh gayr Ilāh
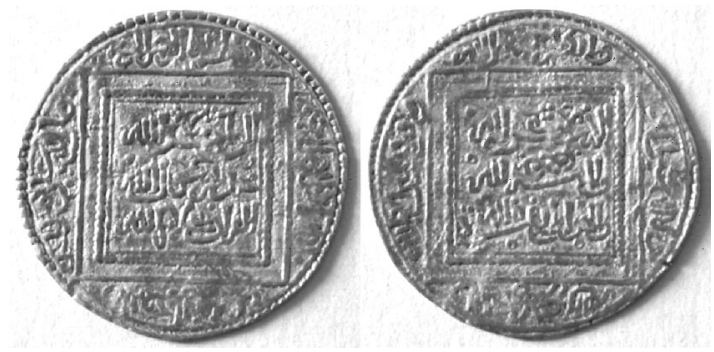
árabes

173 Cf. Lafuente Alcántara, E., Inscripciones árabes, o García Gómez, E., Poemas

${ }^{174}$ Cf. Vega Martín, M. y Peña Martín, M., "Legitimación religiosa".

175 Cf. Hazard, H. W., The Numismatic History, 192 y ss.

176 Dobla meriní inédita; 4,56 g., 30,22 mm. Ø; colección particular.

Al-Qanțara (AQ) XXVII 2, julio-diciembre 2006, pp. 477-527 ISSN 0211-3589 


\begin{tabular}{|c|c|}
\hline I.M & II.M \\
\hline $\begin{array}{l}\text { Bi-sm Allāh al-Raḥmān al-Raḥìm } \\
\text { Sallà Allāh 'alà sayyidi-nā Muhammad } \\
\text { Wa-ilāhu-kum ilāh wāhid } \\
\text { Lā ilāh illā huw al-Raḥmān al-Raḥim }\end{array}$ & $\begin{array}{l}\text { Wa-mā bi-kum min ni'ma fa-min Allāh } \\
\text { Wa-mā tawfìqu illā bi-[A]llāh } \\
\text { Wa-mā l-nașr illā min 'ind Allāh } \\
\text { Wa-lā ilāh gayr ilāh }\end{array}$ \\
\hline $\begin{array}{l}\text { (En nombre de Dios, Clemente, Misericordioso } \\
\text { Dios bendiga a nuestro señor Muhammad } \\
\text { Y vuestro Dios es un Dios solo } \\
\text { No hay Dios sino Él, Clemente, Misericordioso) }\end{array}$ & $\begin{array}{l}\text { (Y vuestra gracia es de Dios } \\
\text { Y mi éxito está sólo en Dios } \\
\text { Y no hay ayuda sino de Dios } \\
\text { Y no hay más dios que un Dios) }\end{array}$ \\
\hline I.C & II.C \\
\hline $\begin{array}{l}\text { Al-Wāhid huw Allāh } \\
\text { Muḥammad rasūl Allāh } \\
\text { Al-Qur'ān kalām Allāh }\end{array}$ & $\begin{array}{l}\text { Al-šukr li-[A]llāh } \\
\text { Wal-minna li-[A]llāh } \\
\text { Wa l-ḥawl wa-l-quwwa bi-[A]llāh }\end{array}$ \\
\hline $\begin{array}{l}\text { (El Uno es Dios } \\
\text { Muhammad es el Enviado de Dios } \\
\text { El Corán es la Palabra de Dios) }\end{array}$ & $\begin{array}{l}\text { (Agradecimiento a Dios } \\
\text { Y reconocimiento a Dios } \\
\text { Y potencia y fuerza son por Dios) }\end{array}$ \\
\hline
\end{tabular}

Lo primero que llama la atención en este texto grabado en la moneda es la ausencia absoluta de epígrafes con referencia al año y lugar de acuñación, y asimismo la omisión de cualquier nombre de persona, sea la autoridad emisora sea algún responsable de ceca, o de dinastía. Precisamente esta ausencia de circunstancias de acuñación y de autoridad emisora es lo que apunta a los Meriníes. Y ello parece confirmarlo, con escaso margen de duda, la presencia en el área central del anverso del epígrafe al-Qur'ān kalām Allāh (El Corán es la Palabra de Dios), donde se plasma la ruptura con el modelo mesiánico que conocemos. Llegados a este punto, es necesario hacer una precisión terminológica importante. La palabra «almohade» procede, como se sabe, del árabe al-muwaḥhid (el que declara la unicidad de Dios). Por una suerte de apropiación, similar a otras formas de manipulación del lenguaje ${ }^{177}$, los descendientes de 'Abd al-Mu'min ibn 'Alī, o sea, los Mu'miníes se lo aplicaron a sí mismos, en clara referencia a la insistencia que su doctrina legitimadora hacía en el monoteísmo. Esta insistencia halló un reflejo manifiesto en el lema numismático de las monedas almohades mu'miníes, donde, como vimos al principio, se repite una y otra vez la declaración coránica Al-amr kullu-h li-[A]llāh monedas.

177 Cf. Vega Martín, M., Peña Martín, S. y Feria García, M. C., El mensaje de las Al-Qanțara (AQ) XXVII 2, julio-diciembre 2006, pp. 477-527 ISSN 0211-3589 
(La disposición toda es de Dios) ${ }^{178}$. A los Mu'miníes los sucedieron cuatro dinastías, ya mencionadas, que se distribuyeron por las diversas zonas del primitivo imperio almohade: los Hafșies en Túnez, los Ziyaníes en Argelia, los Meriníes en Marruecos y los Nazaríes en Andalucía Oriental. Si aceptamos el término almohade (confesor de la unicidad de Dios, monoteísta) como definidor del Estado y la cultura dominados por los Mu'miníes, hemos de aceptarlo también para los de las cuatro dinastías citadas. Y desde luego, son muchos los rasgos comunes a las monedas emitidas por ellas.

Hay buenas razones, en efecto, para defender que hubo una gran comunidad ideológica y cultural entre los cuatro Estados sucesores del gobernado por los Mu'miníes. Y en las monedas esto se aprecia no sólo en las características formales, sino en la gran concentración de leyendas que hacen referencia al hecho de fe del monoteísmo. De ahí que el término «almohade» resulte en extremo impreciso, pues, limitándonos al ámbito de las monedas, la doctrina religiosa legitimadora de todas estas dinastías tiene como aspecto fundamental común la repetición de los diversos aspectos del ser divino único. Almohades, en este sentido, eran tanto los descendientes de 'Abd al-Mu'min ibn 'Alī como los Meriníes, Hafșíes, Ziyaníes y Nazaríes. Las diferencias entre ellos hay que buscarlas, en primer lugar, en el hecho dinástico al que hacen referencias estos mismos nombres como en algunos otros aspectos, de orden teológico. Así, tanto los Mu'miníes como los Hafșíes y, a partir de un momento, con Abū 'Inān Fāris (749-759/1348-1358), también los Meriníes reclaman para sí la jefatura absoluta de la Comunidad y, en consecuencia, se titulan en sus monedas Amīr al-Mu'minīn; en contraste, ni Nazaríes ni Ziyaníes se atrevieron a dar ese paso definitivo, como antes tampoco lo habían hecho los almorávides, que reconocieron siempre el califazgo abbasí. La otra diferencia es, como sabemos, la que precede al colapso del imperio único almohade mu'miní, y tiene que ver con el hecho capital del reconocimiento del Mahdī Ibn Tūmart, como intérprete infalible de la Palabra de Dios, esto es, como guía adecuado hacia la salvación. A esto se debe, por supuesto, la presencia en esta moneda de la inscripción Al-Qur'ān kalām Allāh (El Corán es la Palabra de Dios), que solamente se entiende en alusión a las declaraciones «mahdistas» de

\footnotetext{
178 Y que incidentalmente retomaron los Nazaríes; cf. Martínez Enamorado, "La espada de protocolo del sultán nazarí Muhammad V", Glaudius, XXV (2005), 285-310.
}

Al-Qanțara (AQ) XXVII 2, julio-diciembre 2006, pp. 477-527 ISSN 0211-3589 
la mayoría de las monedas mu'mimíes. De modo que es precisamente esta declaración, donde implícitamente se prescinde del reconocimiento del intérprete infalible, la que constituye la clave de identidad del discurso doctrinal almohade meriní, por distinción del mu'miní. Por otra parte, además de las menciones del Enviado Muhammad, el resto de las inscripciones que nos queda por considerar gira en torno al único ser divino, considerado en Su unicidad y en Su relación con Sus siervos:

Y vuestro Dios es un Dios solo / No hay más Dios que Él, Clemente, Misericordioso / El Uno es Dios / Y vuestra gracia es de Dios / Y mi éxito está sólo en Dios / Y no hay ayuda sino de Dios / Y no hay más dios que un Dios / Agradecimiento a Dios / Y reconocimiento a Dios / Y la potencia y la fuerza están en Dios

Esta acumulación de declaraciones, de fuente coránica y valor monoteísta, podría derivar de modelos textuales como la Profesión de fe de Ibn Tūmart, que antes tradujimos; pero, eso sí, sustituyendo algunos de los rasgos propios de ésta por otros, acordes con concepciones religiosas menos «filosóficas», pues se vinculan manifiestamente con la vivencia devota de la religión que corresponde al misticismo ${ }^{179}$ apoyado por las dinastías nazarí y meriní, y al mismo tiempo más cercanos a la teología afirmativa. Entre los epígrafes monoteístas, es decir, en torno al Dios único, de la moneda destaca la insólita formulación del credo en la unicidad de Dios Wa-lä ilāh gayr Ilāh, que hemos traducido como «Y no hay más dios que un Dios» (Figura $10{ }^{180}$ ).

FiguRA 10.-Detalle del epígrafe Wa-lā ilāh gayr Ilāh

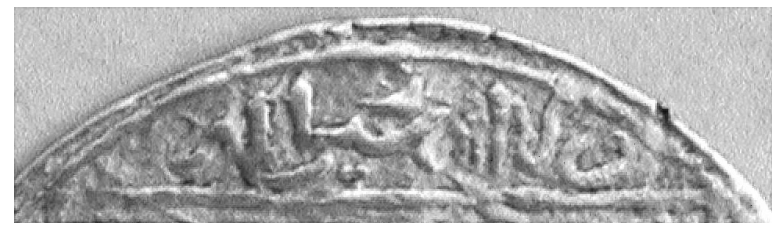

179 Discursos "afirmativos" acerca de Dios no son inexistentes; cf. Hallāj, Le livre de la parole, trad. Abdelamir, Chawki y Delarbre, P., Mónaco, 1996, 19: “Ô Toi qui m’as énivré de Ton amour, qui, dans l'étendue de Ton approche, a jeté le trouble en moi, Tu es Celui qui se singularise par la perpétuité. Tu es Celui qui s'unifie sur les hauteurs du verbe $[\ldots] "$.

${ }^{180}$ Detalle de la dobla meriní, con el epígrafe: Lā ilāh gayr Ilāh.

Al-Qanțara (AQ) XXVII 2, julio-diciembre 2006, pp. 477-527 ISSN 0211-3589 
Hemos de descartar que se trate de un lapsus del diseñador o el grabador, pues la pieza muestra un cuidado extremo en estos aspectos. Téngase en cuenta que la gramaticalidad de la construcción parece garantizada por el hecho, sancionado por la lingüística árabe medieval ${ }^{181}$, de que la unidad que sirve para introducir la restricción en este caso, gayr, es intercambiable con illă, que es la más empleada, por aparecer en la formulación a que estamos acostumbrados: La ilāh illāa Allāh. Y, además, que si bien la formulación con illā es, con diferencia, la más frecuente, hemos encontrado usos de la variedad con gayr, si bien en un texto «marginal» contemporáneo, relacionado con prácticas mágicas ${ }^{182}$, donde se emplea una reformulación muy cercana a la de la moneda meriní: Wa-lā ilāh gayr Allāh. Pero que se trate de una construcción gramatical aceptable y que tengamos constancia de su uso no resta excepcionalidad al epígrafe. A la espera de confirmaciones e indagaciones, el hecho puede conjeturalmente relacionarse con la implantación de la tendencia teológica afirmativa, ya que ha sido propio de las teologías islámicas apofáticas o negativas el interpretar que la formulación más usual, con negación y restricciones absolutas: Lā ilāh illā Allāh, debía entenderse como una declaración apofática acerca del Dios «absolutamente-Otro», inconcebible e inefable para la criatura humana, la cual ha de contentarse no con hablar de la divinidad, sino de su hierofanía Allāh ${ }^{183}$; de modo que la formulación con gayr cerraría la puerta a tales interpretaciones. Pero insistimos en que ésta es una explicación hipotética y provisional, a la espera de otra más convincente.

\section{Un discurso en evolución}

Sin embargo, en refuerzo de la hipótesis de que se trata de una manifestación de teología afirmativa parece venir la última moneda a que nos vamos a referir, de nuevo una fuente de enigmas. Se trata de uno de los ejemplares de una pieza que, según la información no documentada que se nos facilitó, fueron hallados cerca de Málaga. Sea

181 Ibn Fāris, al-Sāhhibī fì fiqh al-luga al-'arabiyya wa-masā'ili-hā wa-sunan al-'arab fì kalāmi-hā, ed. A. Ḥ. Basaŷ, Beirut, 1997, 113.

182 Al-Sihr al-ahmar, s.l., s.d., 19.

183 Cf. Corbin, H., La paradoja del monoteísmo. 
como sea, se trata de una pieza donde ese aire de familia con las monedas del cuadrado, pero sobre todo con las que presentan un cuadrado inscrito en círculo, es manifiesto. Se trata de una pieza de plata, de 0,5 gramo de peso; de manera que puede ser una fracción, sin que podamos precisar dentro de qué sistema metrológico postalmohade hemos de situarla. El hecho es que muestra una evidente comunidad de rasgos con las monedas que hemos atribuido hipotéticamente a Abū 1-'Ulā Idrīs I al-Ma'mūn y con la fracción de dinar que hemos descrito poco más arriba y situado, con reservas, entre las emisiones meriníes. Con esta comparte, además, el rasgo de la tendencia afirmativa en teología, pues su leyenda, también muy escueta, incluye los dos epígrafes siguientes (Figura $11^{184}$ ):

FIGURA 11.-Fracción de dírham postalmohade

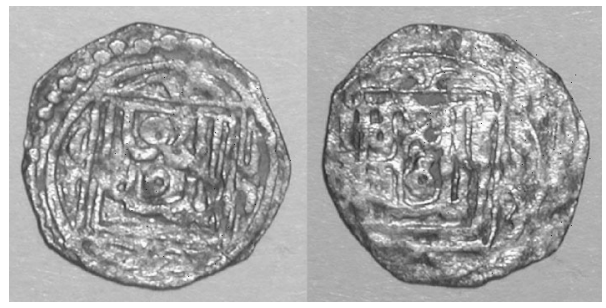

$\begin{array}{ll}\text { I.C } & \text { II.C } \\ \text { Al-haqq } & \text { Al- ‘izza } \\ \text { li-[A]llāh } & \text { li-[A]llāh } \\ & \text { (La verdad } \\ \text { es de Dios) } & \text { es de Dios) }\end{array}$

Con esa base es muy poco lo que puede decirse de la pieza, en cuanto a su atribución dinástica o a la ubicación geográfica de su emisión. Si acaso puede afirmarse, también con ciertas dudas, que debe de tratarse de una moneda inscrita en la reforma impulsada por los Mu'miníes, pero que acusa la crisis del discurso almohade. Todas estas imprecisiones con las que hemos tenido que enfrentarnos no sólo dan la razón a los numísmatas que, como A. Prieto y J. D. de la Rada,

${ }^{184}$ Fracción de dírham postalmohade; 0,5 g., 14,72 mm. Ø; colección particular. 
prefirieron establecer un marco de estudio muy amplio a la hora de describir las monedas del cuadrado, sino que suponen una llamada de atención a la necesidad de que se reinicie el estudio de las monedas almohades y postalmohades. Para ello, es necesario que se crucen, para abordar con ciertas garantías este complejo ámbito numismático: la descripción exhaustiva de hallazgos ${ }^{185} \mathrm{y}$ piezas, tanto de colecciones públicas como privadas ${ }^{186}$; junto con datos epigráficos, metrológicos, históricos, textuales, lingüísticos, teológicos, sin dejar de tener en cuenta los sistemas numismáticos posteriores en el tiempo (como hemos visto en lo referente a las primeras monedas alawíes) y la labor admirable de algunos investigadores de hace varias décadas, cuya obra ha sufrido cierto eclipse en la consideración de los especialistas contemporáneos, a pesar de la magnitud de sus logros. Pensamos en el propio A. Prieto, pero también en los mencionados J. D. Brethes, D. Eustache, H. H. 'Abd al-Wahhāb o J. Farrugia de Candia. A la espera de que esa tarea se realice, hemos de concluir que la indeterminación con que nos hemos ido encontrando a cada paso, y por insatisfactoria y exasperante que pueda resultar a los investigadores contemporáneos, forma parte de ese discurso numismático almohade, sobre cuya evolución hemos tratado de arrojar alguna luz, por más

185 Cf., para lo que respecta a hallazgos de moneda almohade, y además de los ya mencionados, Dieulafoy, M., comunicación sin título, presentada a la Académie des Inscriptions et Belles-Lettres de París, el 3 de febrero de 1905, acerca de un hallazgo, en Granada, de varios centenares de piezas de oro de Abū Yūsuf Ya'qūb I al-Manșūr (Comptes rendus des séances de l'année 1905, 56-58); Barceló Torres, M. C., "Hallazgos de monedas almohades en Villavieja de Nules", Cuadernos de Prehistoria y Arqueología Castellonense, 3 (1976), 301-302; Fontenla Ballesta, S., "Tesorillo de dírhemes de tradición almohade procedente de Melilla", Gaceta Numismática, 97-98 (1990), 143-147; Frochoso Sánchez, R., "El tesorillo de la finca Berlanga de Hornachuelos (Córdoba): estudio comparativo", XIII Congreso Internacional de Numismática (Madrid, 15-19 de septiembre de 2003), Madrid, en prensa.

186 Hay una larga y fecunda tradición de estudios numismáticos basados en una o varias colecciones privadas; entre otros, los de Gaillard, J., Description des monnaies espagnoles et des monnaies étrangères qui ont eu cours en Espagne, depuis les temps les plus reculés jusqu'à nos jours, composant le cabinet monétaire de don José García de la Torre, Madrid, 1852, donde se incluye descripción de buen número de piezas almohades y postalmohades; Brethes, J. D., Contribution à l'étude; Seco de Lucena, L. "Hallazgos de monedas árabes", Al-Andalus, XIX (1954), 467-469, donde se describen, además de unos dírhams almohades (o más bien millareses, a juzgar por la reproducción fotográfica), dos doblas, una almohade y otra hafșí; Daoudi, M., Monnaies médias, Casablanca, 1987; o Ariza Armada, A., "Leyendas monetales, iconografía y legitimación en el califato hammūdí: las emisiones de "Alī b. Hammūd del año 408/1017-1018", Al-Qantara, XXV, 1 (2004), 203-231.

Al-Qanțara (AQ) XXVII 2, julio-diciembre 2006, pp. 477-527 ISSN 0211-3589 
que ello haya supuesto señalar nuevas zonas oscuras. Sin embargo, es necesario reconocer que esa «oscuridad» proviene del propio discurso numismático almohade y postalmohade, donde tantos casos de ambigüedad o indeterminación hemos visto. Este hecho, la falta de claridad en el mensaje, debería llevarnos tal vez a replantear, al menos en lo que respecta a las monedas, las conclusiones sobre la existencia y fortaleza de un discurso propagandístico almohade, idea que tanta aceptación ha logrado en las fuentes secundarias ${ }^{187}$. Pues, ¿no es una contradictio in terminis el que un discurso propagandístico sea oscuro y por tanto inaccesible a los no iniciados? Mucho más, si tenemos en cuenta que, como ha afirmado recientemente M. Fierro ${ }^{188}$, «el grado de penetración social de las nuevas elites almohades parece haber sido muy limitado». Asimismo en un trabajo reciente J. Zozaya ${ }^{189}$ ha afrontado el estudio de la iconografía en la cerámica almohade desde presupuestos muy cercanos a la simbología esotérica; y esto, junto con lo que hemos visto del indeterminado discurso numismático, tal vez debe conducirnos a afirmar que una parte importante del sistema de mensajes almohades y postalmohades iba dirigido a los grupos reducidos de las elites, los intelectuales orgánicos de los sucesivos regímenes, para quienes sí podía estar claro el mensaje, de gran profundidad y complejidad, y con indicios tales de contener elementos crípticos que nos obligan a plantear la posibilidad de que estuviese entreverado de esoterismo.

\section{Recapitulación}

Nuestro recorrido diacrónico por las monedas acuñadas en virtud de las reformas almohades nos ha llevado a proponer nuevas lecturas de epígrafes conocidos y a registrar varias series inéditas de monedas; lo cual nos ha proporcionado base suficiente para plantear o discutir

${ }^{187} \mathrm{~A}$ r respecto y entre otros, varios excelentes trabajos: Acién Almansa, M., "Cerámica y propaganda en época almohade", Arqueología Medieval, IV (1996), 183-191; Fontenla Ballesta, S., "Numismática y propaganda"; Marín, M., "El califa almohade"; Martínez Núñez, M. A., "Ideología y epigrafía".

188 "Doctrina y práctica jurídicas bajo los almohades", Los Almohades: problemas y perspectivas, II, 895-935, 908-909.

189 "Objetos mobiliarios almohades: formas simbólicas y de ornamentación”, Los Almohades: problemas y perspectivas, 353-385.

Al-Qanțara (AQ) XXVII 2, julio-diciembre 2006, pp. 477-527 ISSN 0211-3589 
los siguientes aspectos, de trascendencia para la constitución del discurso religioso en el Occidente islámico durante la Baja Edad Media:

1. Hemos comprobado que el discurso numismático almohade tiene un palimpsesto privilegiado en el Corán, como fuente absoluta.

2. Y cómo a partir de textos coránicos se construye un discurso en el que resalta la densidad del contenido escatológico (acerca de la vida en el más allá).

3. También es el mensaje coránico el que da pie a una «discusión» en las monedas acerca de la necesidad de guías históricos para la salvación de los fieles.

4. De ahí que las monedas reflejen la inestabilidad del componente mahdista en los discursos religiosos y de legitimación posteriores a la irrupción del movimiento encabezado por Ibn Tūmart.

5. Con todo, el discurso numismático de las llamadas monedas del cuadrado no es estático, sino que parece reflejar, además de las tensiones indicadas, un paso de la teología negativa a la afirmativa.

6. Pero, de una u otra forma, el peso de concepciones hierocráticas o cercanas al hierocratismo ha ejercido una influencia efectiva en la constitución del sistema ideológico compartido, hasta cierto punto, por el Estado almohade y por los cuatro Estados a que dio lugar su fragmentación.

7. Se reafirma, así, lo adecuado de ampliar, al constituir el campo de estudio almohade, la visión a las monedas emitidas por los Estados postalmohades.

8. La indeterminación propia del discurso numismático almohade nos ha llevado a defender la posibilidad de que se trate de una manifestación condensada del sistema de ideas teológicas y cosmológicas sustentadas por la elite intelectual almohade. 